\title{
Cutting a Gordian Knot: Emended Classification and Description of the Genus Flavobacterium, Emended Description of the Family Flavobacteriaceae, and Proposal of Flavobacterium hydatis nom. nov. (Basonym, Cytophaga aquatilis Strohl and Tait 1978)
}

\author{
J.-F. BERNARDET, ${ }^{1 *}$ P. SEGERS, ${ }^{2}$ M. VANCANNEYT, ${ }^{2}$ F. BERTHE, ${ }^{1}$ \\ K. KERSTERS, ${ }^{2}$ AND P. VANDAMME ${ }^{2}$ \\ Unité de Virologie et Immunologie Moléculaires, Institut National de la Recherche Agronomique, \\ 78352 Jouy-en-Josas Cedex, France, ${ }^{1}$ and Laboratorium voor Microbiologie, \\ Faculteit Wetenschappen, University of Ghent, B-9000 Ghent, Belgium ${ }^{2}$
}

\begin{abstract}
The phylogenetic positions and $\mathrm{G}+\mathrm{C}$ contents of most species belonging to the genera Flavobacterium, Cytophaga, and Flexibacter and several related taxa were determined. Most of the strains included in this study belong to rRNA superfamily $V$, as shown by DNA-rRNA hybridization data, but the three main genera are highly polyphyletic. Several so-called Cytophaga and Flexibacter species isolated from soil and freshwater cluster with the type species of the genus Flavobacterium, Flavobacterium aquatile, and with Flavobacterium branchiophilum. The fatty acid and protein profiles of members of this group of organisms were determined. We provide an emended description of the genus Flavobacterium and propose new combinations for the following 7 of the 10 validly described species included in this genus: Flavobacterium columnare, Flavobacterium flevense, Flavobacterium johnsoniae (we also correct the specific epithet of this taxon), Flavobacterium pectinovorum, Flavobacterium psychrophilum, Flavobacterium saccharophilum, and Flavobacterium succinicans. A new name, Flavobacterium hydatis, is proposed for [Cytophaga] aquatilis Strohl and Tait 1978. The emended genus Flavobacterium contains bacteria that have the following main characteristics: gram-negative rods that are motile by gliding, produce yellow colonies on agar, are chemoorganotrophs and aerobes, decompose several polysaccharides but not cellulose, and are widely distributed in soil and freshwater habitats. Three Flavobacterium species are pathogenic for fish. The G+C contents of Flavobacterium DNAs range from 32 to $37 \mathrm{~mol} \%$. An emended description of the family Flavobacteriaceae is also provided.
\end{abstract}

The long and complex history of the genera Flavobacterium, Cytophaga, and Flexibacter and the heterogeneity of these genera have been well documented. The most recent reviews of the taxonomy of these organisms were published in Bergey's Manual of Systematic Bacteriology $(40,68)$, in The Prokaryotes 2nd ed. (37,69), and in Advances in the Taxonomy and Significance of Flavobacterium, Cytophaga and Related Bacteria (38, $70)$. Because of the numerous phenotypic similarities of Flavobacterium, Cytophaga, and Flexibacter strains, for a long time differentiation of these genera has been based on the presence (in the genera Cytophaga and Flexibacter) or absence (in the genus Flavobacterium) of gliding motility. This characteristic, whose relevance for genus delineation has been questioned, is probably an ancestral property of this bacterial group that was lost by some organisms in the course of evolution $(68,101)$.

The genus Flavobacterium was created in 1923 (7) to accommodate gram-negative, non-spore-forming, yellow-pigmented rods that produce acid from carbohydrates weakly (40). Because of this limited definition, the genus rapidly acquired many poorly defined species and consequently became very heterogeneous. However, through successive emendations, the genus Flavobacterium was restricted to nonmotile and nongliding species and thus achieved what could be considered reasonable homogeneity in Bergey's Manual of Systematic Bacteriology (40). The acceptability of Flavobacterium aquatile as the

\footnotetext{
* Corresponding author. Phone: (33) 1 34-65-25-87. Fax: (33) 1 34-65-25-91.
}

type species of the genus Flavobacterium has been discussed repeatedly $(37,38,40)$. This species is represented by a single strain, which is not the strain that was described originally, and several studies have demonstrated that Flavobacterium aquatile is indeed more closely related to certain Cytophaga species than to other Flavobacterium species; Flavobacterium aquatile exhibits swarming and gliding motility under certain conditions, and the structure of its cell wall is similar to that of [Cytophaga] johnsonae (29) (brackets indicate generically misclassified bacteria). As Flavobacterium aquatile was not considered representative of the genus, Holmes and Owen requested that this name be rejected as a nomen dubium and the species be replaced with Flavobacterium breve as the type species of the genus (39). Because this request was denied by the Judicial Commission (96), Flavobacterium aquatile must be retained as the type species. Several species previously placed in the genus Flavobacterium have been reclassified and placed in new or different genera, including the genera Bergeyella (85), Cytophaga (68), Empedobacter (85), Sphingobacterium (37, 102), and Weeksella $(37,43,44)$. Recently, the genus Chryseobacterium has been proposed for several species previously included in the genus Flavobacterium; some of these species are found in aquatic environments, while others are human or fish pathogens (85). Several new Flavobacterium species have also been described recently $(24,54)$.

The genus Cytophaga, which was created in 1929 by Winogradsky for aerobic cellulolytic gliding soil bacteria, was subsequently expanded to include many environmental gliding 
organisms that degrade several polysaccharides (e.g., agar, chitin, pectin, heparin, and carboxymethyl cellulose) but form neither microcysts nor fruiting bodies (68). As a consequence, this genus also became very heterogeneous. The same is true for the genus Flexibacter, which was created by Soriano in 1945 for soil and freshwater bacteria that were phenotypically similar to Cytophaga strains but were not able to degrade cellulose (77). The description of the genus Flexibacter was later emended so that it included organisms that produced long, slender, thread-like cells in young cultures, did not degrade any polysaccharide, and produced yellow, red, or pink pigments (50). Because these criteria were not sound and failed to deal with the obvious heterogeneity of the genera Cytophaga and Flexibacter, Reichenbach proposed that these two genera should be distinguished on the basis of changes in cell morphology in aging cultures, $\mathrm{G}+\mathrm{C}$ content ranges, and habitats (68). The bacterial species that were similar to Flexibacter species but were isolated from marine environments were placed in the genus Microscilla, which was described by Pringsheim in 1951 (66) and was emended by Lewin $(50,68)$.

Since the mid-1980s, 16S rRNA oligonucleotide catalog (63) and sequence $(30,45,56,59,100,101)$ data and DNA-rRNA hybridization data $(6,72,73,85)$ have shown that the genera Flavobacterium, Cytophaga, and Flexibacter belong to one of the 10 main phylogenetic branches of the Bacteria. Depending on the authors, this branch is called the Cytophaga-Flavobacterium-Bacteroides group, rRNA superfamily V (73), or the "flavobacter-bacteroides" phylum (30). More surprising is the fact that this group, which is composed of aerobic bacteria for the most part, also includes the capnophilic genera Capnocytophaga, Riemerella, and Ornithobacterium $(58,72,88)$ and the obligately anaerobic genera Bacteroides (63), Mitsuokella (36), Prevotella, Porphyromonas, and Rikenella (62). Additional data have revealed that the following other taxa also belong to the Cytophaga-Flavobacterium-Bacteroides group: the family Spirosomaceae (including the genera Spirosoma, Runella, Flectobacillus, and Cyclobacterium) $(67,98)$, the recently described genus "Taxeobacter" (names in quotation marks have not been validly published) (71), and the genera Saprospira, Haliscomenobacter, Microscilla, Flexithrix, Sporocytophaga, and Chitinophaga (68). In addition, phylogenetic analyses have revealed that two thermophilic organisms, Thermonema lapsum (64) and Rhodothermus marinus (5), are also included in the Cytophaga-Flavobacterium-Bacteroides group. Recent data from 23S rRNA sequencing studies have suggested that the closest relatives of the Flavobacterium-Bacteroides-Cytophaga group are the green sulfur bacteria (99).

The following branches of rRNA superfamily $V$ have been studied previously in detail by the DNA-rRNA hybridization technique: the Chryseobacterium-Bergeyella-Riemerella branch $(72,85)$; the Weeksella-Empedobacter branch (85); and the Ornithobacterium, Capnocytophaga, and Sphingobacterium branches $(72,80,81,88)$. In order to determine the phylogenetic relationships within the Cytophaga-Flavobacterium-Bacteroides group more precisely, we performed extensive DNA-rRNA hybridization experiments and determined guanine-plus-cytosine $(\mathrm{G}+\mathrm{C})$ contents; in this study we used the type strains and well-characterized isolates of most valid and invalid species belonging to the genera Cytophaga and Flexibacter, as well as several members of the genera Flavobacterium and Sphingobacterium and related taxa. One major rRNA cluster, which contained the type species of the genus Flavobacterium, Flavobacterium aquatile, was also studied by using a polyphasic approach that included fatty acid analysis and sodium dodecyl sulfate (SDS)-polyacrylamide gel electrophoresis (PAGE) of whole-cell proteins in order to determine the relationships at the generic level. Because of the phenotypic similarity between [Cytophaga] johnsonae and [Flexibacter] aurantiacus, DNADNA hybridization experiments were performed with four [Cytophaga] johnsonae strains and the only two [Flexibacter] aurantiacus strains available in order to determine the levels of DNA relatedness of these organisms.

Our results showed that the genera Cytophaga and Flexibacter are highly polyphyletic and that most Cytophaga and Flexibacter species are only distantly related to their respective type species (i.e., Cytophaga hutchinsonii and Flexibacter flexilis, respectively). Several of these generically misnamed species, including soil and freshwater isolates, are close relatives of Flavobacterium aquatile and have a considerable number of phenotypic and chemotaxonomic characteristics in common. Therefore, we propose that these species should be transferred to an emended genus Flavobacterium that has Flavobacterium aquatile as its type species. Because of the high levels of DNA relatedness between the [Cytophaga] johnsonae type strain and the two [Flexibacter] aurantiacus strains, we also propose that [Flexibacter] aurantiacus strains should be transferred to the species [Cytophaga] johnsonae.

\section{MATERIALS AND METHODS}

Bacterial strains and growth conditions. The strains included in this study are shown in Table 1 along with their sources and the growth media used for them. Most of the bacteria were grown at $25^{\circ} \mathrm{C}$; the exceptions were [Flexibacter] ovolyticus and [Flexibacter] psychrophilus, which were grown at $19^{\circ} \mathrm{C}$, and $[$ Flec tobacillus] glomeratus, which was grown at $15^{\circ} \mathrm{C}$. The following media were used to grow the bacteria: Dubos mineral medium (69) supplemented with $1 \%$ (wt) vol) D-cellobiose; marine medium 2216E (Difco Laboratories, Detroit, Mich.); Microcyclus-Spirosoma medium (medium 81 [57a]); modified Shieh medium (76); and Trypticase soy medium (BBL, Becton Dickinson Microbiology Systems, Cockeysville, Md.). Most of the bacteria were grown on agar plates; the only exceptions were the [Flexibacter] columnaris strains, which were grown in liquid medium because their colonies adhered strongly to agar.

Preparation of DNA. Previously described methods (12) were used to extract and purify high-molecular-weight native DNAs.

DNA base composition. The $G+C$ contents of the DNAs were determined by the thermal denaturation method and were calculated by using the equation of Marmur and Doty (51), as modified by De Ley (21).

DNA-DNA hybridization experiments. A previously described procedure was used for in vitro labeling of bacterial DNA (nick translation) with tritium-labeled nucleotides (Amersham International, Amersham, England) (31); the only modification was that a nick translation kit (Amersham International) was used in this study. Previously described methods were used for hybridization experiments (the S1 nuclease-DE81 method) (65) and for determining the temperature $\left(T_{m}\right)$ at which $50 \%$ of a reassociated DNA became hydrolyzable by $S 1$ nuclease (17). The difference between the $T_{m}$ of a homologous reaction and the $T_{m}$ of a heterologous reaction $\left(\Delta T_{m}\right)$ was an estimate of the level of divergence between two DNAs.

Preparation of rRNA. The rRNAs of [Flexibacter] columnaris NCIMB $2248^{\mathrm{T}}$ ( $\mathrm{T}=$ type strain), [Flexibacter] maritimus NCIMB $2154^{\mathrm{T}}$, Cytophaga hutchinsonii LMG $10844^{\mathrm{T}}$, and Flexibacter flexilis NCIMB $12853^{\mathrm{T}}$ were radioactively labeled in vivo by adding ${ }^{3} \mathrm{H}$-labeled adenine to early-log-phase broth cultures as described by De Ley and De Smedt (23). The labeled rRNAs were extracted by the method of Aiba et al. (2) (slightly modified as described by Vandamme et al. [88]) and were separated into $23 \mathrm{~S}$ and $16 \mathrm{~S}$ rRNA fractions by ultracentrifugation on a sucrose gradient (23). Labeled Flavobacterium aquatile LMG $4008^{\mathrm{T}}$, Sphingobacterium heparinum LMG $10339^{\mathrm{T}}$, and Sphingobacterium spiritivorum LMG $8347^{\mathrm{T}}$ rRNAs were prepared by the same method during a previous study (72).

DNA-rRNA hybridization experiments. Previously described methods (91) were used for fixation of single-stranded DNAs on cellulose nitrate filters, determination of the amount of DNA fixed on filters, saturation hybridization with labeled rRNAs, RNase treatment, and determination of the thermostability of DNA-rRNA hybrids

FAME analysis. We determined fatty acid methyl ester (FAME) profiles of strains belonging to the Flavobacterium aquatile rRNA cluster (see below). Most of the bacteria were grown on modified Shieh agar for $48 \mathrm{~h}$ at $25^{\circ} \mathrm{C}$ (the only exception was [Flexibacter] psychrophilus, which was grown at $19^{\circ} \mathrm{C}$ ), and the cells were harvested and used for FAME extraction. The FAMEs were then separated by gas-liquid chromatography, and the FAME profiles obtained were compared by performing a numerical analysis (93).

PAGE of whole-cell proteins. Protein patterns were determined for the same taxa that were used in the FAME analysis, which were grown under the condi- 
TABLE 1. Bacterial strains used in this study

\begin{tabular}{|c|c|c|c|c|}
\hline Name as received & $\begin{array}{l}\text { Strain designation } \\
\text { as received }{ }^{a}\end{array}$ & LMG no. ${ }^{a}$ & Medium $^{b}$ & Source \\
\hline Chitinophaga pinensis & & LMG $13176^{\mathrm{T}}$ & $\mathrm{S}$ & Pine litter, Brisbane, Australia \\
\hline Chitinophaga pinensis & & LMG 13042 & $\mathrm{~S}$ & Freshwater, Queensland, Australia \\
\hline Cyclobacterium marinus & & LMG $13164^{\mathrm{T}}$ & $\mathrm{M}$ & Coelomic fluid of sand dollar, California \\
\hline [Cytophaga] agarovorans & NCIMB $2217^{\mathrm{T}}$ & LMG $13037^{\mathrm{T}}$ & $\mathrm{M}$ & Marine mud, California \\
\hline "[Cytophaga] allerginae" & ATCC 35408 & & $\mathrm{~S}$ & Water in air-cooling unit, Florida \\
\hline [Cytophaga] aprica & ATCC $23126^{\mathrm{T}}$ & & $\mathrm{M}$ & Rocky sand, Kailua, Hawaii \\
\hline [Cytophaga] aprica & NCIMB 1411 & & M & Mud, Dubrovnik, Yugoslavia \\
\hline [Cytophaga] aquatilis & DSM $2063^{\mathrm{T}}$ & LMG $8385^{\mathrm{T}}$ & $\mathrm{S}$ & Gills of diseased salmon, Michigan \\
\hline [Cytophaga] arvensicola & JCM $2836^{\mathrm{T}}$ & LMG $8359^{\mathrm{T}}$ & $\mathrm{S}$ & Soil, Osaka, Japan \\
\hline Cytophaga aurantiaca & NCIMB $8628^{\mathrm{T}}$ & LMG $1337^{\mathrm{T}}$ & $\mathrm{C}$ & Swampy soil, Germany \\
\hline [Cytophaga] diffluens & NCIMB $1402^{\mathrm{T}}$ & LMG $13036^{\mathrm{T}}$ & $\mathbf{M}$ & Beach mud, Bombay, India \\
\hline [Cytophaga] fermentans & NCIMB $2218^{\mathrm{T}}$ & LMG $1338^{\mathrm{T}}$ & $\mathrm{M}$ & Marine mud, California \\
\hline [Cytophaga] flevensis & DSM $1076^{\mathrm{T}}$ & LMG $8328^{\mathrm{T}}$ & $\mathrm{S}$ & Lake Ijssel, The Netherlands \\
\hline Cytophaga hutchinsonii & & LMG $10844^{\mathrm{T}}$ & $\mathrm{C}$ & Soil \\
\hline Cytophaga hutchinsonii & NCIMB 10782 & LMG 13160 & $\mathrm{C}$ & Soil \\
\hline [Cytophaga] johnsonae & DSM $2064^{\mathrm{T}}$ & LMG $1341^{\mathrm{T}}$ & $\mathrm{S}$ & Soil or mud, Rothamsted or Cambridge, England \\
\hline [Cytophaga] johnsonae & ATCC 29585 & LMG 1342 & S & Diseased freshwater fish, Manitoba, Canada \\
\hline [Cytophaga] johnsonae & ATCC 29586 & & $\mathrm{~s}$ & Diseased freshwater fish, Manitoba, Canada \\
\hline [Cytophaga] johnsonae & Cy j1 ${ }^{c}$ & LMG 13142 & $\mathrm{~S}$ & Root surface of grass, Scotland \\
\hline [Cytophaga] johnsonae & NCIMB 11391 & LMG 13161 & $\mathrm{~s}$ & Soil \\
\hline [Cytophaga] johnsonae & UASM $405^{d}$ & & S & Soil, Ottawa, Ontario, Canada \\
\hline [Cytophaga] johnsonae & UASM $444^{d}$ & & $\mathrm{~s}$ & Unknown \\
\hline "[Cytophaga] keratolytica" & & LMG 11610 & $S$ & Unknown \\
\hline [Cytophaga] latercula & NCIMB $1399^{\mathrm{T}}$ & LMG $1343^{\mathrm{T}}$ & M & Outflow of marine aquarium, La Jolla, Calif. \\
\hline [Cytophaga] lytica & NCIMB $1423^{\mathrm{T}}$ & LMG $1344^{\mathrm{T}}$ & M & Beach mud, Limon, Costa Rica \\
\hline [Cytophaga] lytica & DSM $2040^{\circ}$ & LMG 13155 & $\mathbf{M}$ & Outflow of marine aquarium, La Jolla, Calif. \\
\hline [Cytophaga] marinoflava & NCIMB $397^{\mathrm{T}}$ & LMG $1345^{\mathrm{T}}$ & $\mathbf{M}$ & Seawater off Aberdeen, Scotland \\
\hline [Cytophaga] pectinovora & NCIMB $9059^{\mathrm{T}}$ & LMG $4031^{\mathrm{T}}$ & $\mathrm{S}$ & Soil, England \\
\hline [Cytophaga] saccharophila & NCIMB $2072^{\mathrm{T}}$ & LMG $8384^{\mathrm{T}}$ & $\mathrm{S}$ & River Wey, Surrey, England \\
\hline [Cytophaga] salmonicolor & NCIMB $2216^{\mathrm{T}}$ & LMG $1346^{\mathrm{T}}$ & M & Marine mud, California \\
\hline [Cytophaga] succinicans & NCIMB $2277^{\mathrm{T}}$ & LMG $10402^{\mathrm{T}}$ & $\mathbf{S}$ & Eroded fin of salmon, Washington \\
\hline [Cytophaga] succinicans & NCIMB 2278 & & $\mathrm{~S}$ & Lesion of salmon, Snake River, Idaho \\
\hline [Cytophaga] succinicans & NCIMB 2279 & & $\mathrm{~S}$ & Water from a fish tank, Washington \\
\hline [Cytophaga] uliginosa & NCIMB $1863^{\mathrm{T}}$ & LMG $3809^{\mathrm{T}}$ & $\mathbf{M}$ & Marine sediment \\
\hline "[Cytophaga] xantha" & & LMG $8372^{\mathrm{T}}$ & $\mathrm{S}$ & Showa Station, Antarctica \\
\hline Flavobacterium aquatile & & LMG $4008^{\mathrm{T}}$ & $\mathrm{S}$ & Deep well, Kent, England \\
\hline Flavobacterium branchiophilum & ATCC $35035^{\mathrm{T}}$ & LMG $13707^{\mathrm{T}}$ & S & Diseased gills of fish, Gumma, Japan \\
\hline Flavobacterium branchiophilum & NCIMB 2219 & & $\mathrm{~S}$ & $\begin{array}{l}\text { Diseased gills of fish, Bonneville Hatchery, } \\
\text { Oregon }\end{array}$ \\
\hline Flavobacterium branchiophilum & BGD $7736^{f}$ & & $\mathrm{~S}$ & Diseased gills of fish, Gumma, Japan \\
\hline Flavobacterium branchiophilum & FL- $15^{f}$ & & $\mathrm{~S}$ & Diseased gills of sheatfish, Hungary \\
\hline Flavobacterium branchiophilum & THP- $1^{f}$ & & $\mathrm{~S}$ & Diseased gills of fish, Tokushima, Japan \\
\hline Flavobacterium branchiophilum & FDL- $1^{f}$ & & $\mathrm{~S}$ & Diseased gills of fish, South Santiam, Oreg. \\
\hline Flavobacterium branchiophilum & BV $-6^{f}$ & & S & $\begin{array}{l}\text { Diseased gills of fish, Bonneville Hatchery, } \\
\text { Oregon }\end{array}$ \\
\hline [Flavobacterium] ferrugineum & & LMG $10403^{\mathrm{T}}$ & $\mathrm{T}$ & Unknown \\
\hline [Flavobacterium] gondwanense & & LMG $13192^{\mathrm{T}}$ & $\mathbf{M}$ & Water, Organic Lake, Antarctica \\
\hline [Flavobacterium] gondwanense & ACAM $46^{\circ}$ & & M & Water, Organic Lake, Antarctica \\
\hline [Flavobacterium] odoratum & & LMG $1233^{\mathrm{T}}$ & $\mathrm{S}$ & Unknown \\
\hline [Flavobacterium] odoratum & & LMG 4028 & $\mathbf{S}$ & Urine, England \\
\hline [Flavobacterium] odoratum & & LMG 4029 & $\mathrm{~S}$ & Wound swab, England \\
\hline [Flavobacterium] salegens & & LMG $13193^{\mathrm{T}}$ & $\mathbf{M}$ & Water, Organic Lake, Antarctica \\
\hline [Flavobacterium] salegens & ACAM $52^{g}$ & & $\mathbf{M}$ & Water, Organic Lake, Antarctica \\
\hline "[Flavobacterium] tirrenicum" & $\mathrm{Fv} \mathrm{t} 1^{\mathrm{Tc}}$ & LMG $4037^{\mathrm{T}}$ & M & Seawater, Gulf of Naples, Italy \\
\hline [Flectobacillus] glomeratus & & LMG $13858^{\mathrm{T}}$ & $\mathbf{M}$ & Water, Burton Lake, Antarctica \\
\hline Flectobacillus major & & LMG $13163^{\mathrm{T}}$ & $\mathrm{S}$ & Algal culture, Russia \\
\hline [Flexibacter] aurantiacus & NCIMB $1382^{\mathrm{T}}$ & LMG $3987^{\mathrm{T}}$ & $\mathrm{S}$ & Garden soil, Minneapolis, Minn. \\
\hline [Flexibacter] aurantiacus & NCIMB 1455 & LMG 10404 & $\mathbf{S}$ & Unknown \\
\hline "[Flexibacter] aurantiacus subsp. copepodarum" & & LMG $10405^{T}$ & $\mathbf{M}$ & Offshore copepod, La Jolla, Calif. \\
\hline "[Flexibacter] aurantiacus subsp. excathedrus" & & LMG $3986^{\mathrm{T}}$ & $\mathrm{S}$ & Pool in cathedral, Cartago, Costa Rica \\
\hline [Flexibacter] canadensis & & LMG $8368^{\mathrm{T}}$ & $\mathrm{T}$ & Soil, Canada \\
\hline [Flexibacter] columnaris & NCIMB $2248^{\mathrm{T}}$ & LMG $13035^{\mathrm{T}}$ & $\mathrm{S}$ & $\begin{array}{l}\text { Kidney of diseased salmon, Snake River, } \\
\text { Washington }\end{array}$ \\
\hline [Flexibacter] columnaris & DD3-69 $9^{h}$ & & $\mathbf{S}$ & Gill lesion of salmon, Dexter Dam, Oregon \\
\hline [Flexibacter] columnaris & JIP $44 / 87$ & & S & $\begin{array}{l}\text { Skin lesion of brown trout, Basse Normandie, } \\
\text { France }\end{array}$ \\
\hline [Flexibacter] columnaris & $\mathrm{CR} 7^{i}$ & & $\mathrm{~S}$ & Jaw erosion of trout, Finland \\
\hline
\end{tabular}


TABLE 1-Continued

\begin{tabular}{|c|c|c|c|c|}
\hline Name as received & $\begin{array}{l}\text { Strain designation } \\
\text { as received }{ }^{a}\end{array}$ & LMG no. ${ }^{a}$ & Medium $^{b}$ & Source \\
\hline [Flexibacter] columnaris & $\mathrm{CR} 8^{i}$ & & $\mathrm{~S}$ & Tail lesion of salmon, Finland \\
\hline [Flexibacter] elegans & & LMG $10750^{\mathrm{T}}$ & $\mathrm{T}$ & Hot spring, Rotorua, New Zealand \\
\hline [Flexibacter] filiformis & ATCC $29495^{\mathrm{T}}$ & LMG $10391^{\mathrm{T}}$ & $\mathrm{T}$ & Soil, Upolu, Apia, Samoa \\
\hline Flexibacter flexilis & NCIMB $12853^{\mathrm{T}}$ & LMG $3989^{\mathrm{T}}$ & $S$ & Lily pond, San Jose, Costa Rica \\
\hline "[Flexibacter $]$ flexilis subsp. algavorum" & DSM $4510^{\mathrm{Te}}$ & LMG $13158^{\mathrm{T}}$ & S & Pond, Saint Petersburg, Russia \\
\hline "[Flexibacter] flexilis subsp. pelliculosus" & & LMG $3991^{\mathbf{T}}$ & $\mathrm{S}$ & Shore of Birch Lake, Minnesota \\
\hline [Flexibacter] litoralis & NCIMB $1366^{\mathrm{T}}$ & LMG $3992^{\mathrm{T}}$ & M & Outflow of marine aquarium, La Jolla, Calif. \\
\hline [Flexibacter] maritimus & NCIMB $2154^{\mathrm{T}}$ & LMG $11612^{\mathrm{T}}$ & M & Kidney of diseased sea bream, Hiroshima, Japan \\
\hline [Flexibacter] maritimus & NCIMB 2153 & & M & Kidney of diseased sea bream, Hiroshima, Japan \\
\hline [Flexibacter] maritimus & NCIMB 2158 & LMG 13038 & M & Skin lesion of Dover sole, Hunterston, Scotland \\
\hline [Flexibacter] ovolyticus & $\mathrm{EKD} 002^{\mathrm{T} j}$ & LMG $13026^{\mathrm{T}}$ & M & $\begin{array}{l}\text { Adherent epiflora of halibut eggs, Austevoll, } \\
\text { Norway }\end{array}$ \\
\hline [Flexibacter] ovolyticus & VKB $004^{\prime}$ & LMG 13027 & M & $\begin{array}{l}\text { Water in halibut egg incubator, Austevoll, } \\
\text { Norway }\end{array}$ \\
\hline [Flexibacter] psychrophilus & NCIMB $1947^{\mathrm{T}}$ & LMG $13179^{\mathrm{T}}$ & $\mathrm{S}$ & Kidney of coho salmon, Washington \\
\hline [Flexibacter] psychrophilus & & LMG 10400 & $\mathrm{~S}$ & Salmon, Minter Creek Hatchery, Washington \\
\hline [Flexibacter] psychrophilus & SH3-81 ${ }^{h}$ & & $S$ & Kidney of coho salmon, Oregon \\
\hline [Flexibacter] psychrophilus & FPC $830^{f}$ & LMG 13183 & $\mathrm{~S}$ & Coho salmon, Migayi, Japan \\
\hline [Flexibacter] psychrophilus & JIP $22 / 90$ & & $S$ & $\begin{array}{l}\text { Skin lesion of brown trout, Nord-Pas-de-Calais, } \\
\text { France }\end{array}$ \\
\hline [Flexibacter] roseolus & ATCC $23088^{\mathrm{T}}$ & LMG $13507^{\mathrm{T}}$ & $\mathrm{S}$ & Hot spring, Agua Caliente, Costa Rica \\
\hline [Flexibacter] ruber & ATCC $23103^{\mathrm{T}}$ & LMG $13508^{\mathrm{T}}$ & $\mathrm{S}$ & Hot spring, Geysir, Iceland \\
\hline [Flexibacter] sancti & NCIMB $1379^{\mathrm{T}}$ & LMG $8377^{\mathrm{T}}$ & $\mathrm{S}$ & Soil, Buenos Aires, Argentina \\
\hline Flexithrix dorotheae & Ft d1 ${ }^{\mathrm{T} c}$ & LMG $8379^{\mathrm{T}}$ & M & Beach silt, Ernakulum, Kerala, India \\
\hline Haliscomenobacter hydrossis & & LMG $10767^{\mathrm{T}}$ & $\mathrm{N}$ & Activated sludge, Oss, The Netherlands \\
\hline "Microscilla aggregans" & NCIMB $1443^{\mathrm{T}}$ & LMG $8376^{\mathrm{T}}$ & M & Sand, Canoe Beach, Tema, Ghana \\
\hline "Microscilla aggregans" & & LMG 13137 & $\mathrm{M}$ & Sand, Ernakulum, Kerala, India \\
\hline "Microscilla arenaria" & NCIMB $1413^{\mathrm{T}}$ & LMG $13024^{\mathrm{T}}$ & M & $\begin{array}{l}\text { Sand, Norse Beach, Puerto Peñasco, Sonora, } \\
\text { Mexico }\end{array}$ \\
\hline "Microscilla furvescens" & NCIMB $1419^{\mathrm{T}}$ & LMG $13023^{\mathrm{T}}$ & M & Sand, Samoa \\
\hline Microscilla marina & NCIMB $1400^{\mathrm{T}}$ & LMG $13022^{\mathrm{T}}$ & $\mathrm{M}$ & Outflow of marine aquarium, La Jolla, Calif. \\
\hline "Microscilla sericea" & NCIMB $1403^{\mathrm{T}}$ & LMG $13021^{\mathrm{T}}$ & M & Outflow of marine aquarium, La Jolla, Calif. \\
\hline "Microscilla tractuosa" & NCIMB $1408^{\mathrm{T}}$ & LMG $8378^{\mathrm{T}}$ & $\mathrm{M}$ & Sand, Nhatrang, Vietnam \\
\hline "[Promyxobacterium $]$ flavum" & & LMG $10389^{\mathrm{T}}$ & $\mathrm{S}$ & Rhizosphere of tomato plant, Russia \\
\hline Runella slithyformis & & LMG $11500^{\mathrm{T}}$ & $\mathrm{N}$ & Freshwater lake near Baton Rouge, La. \\
\hline Saprospira grandis & & LMG $10407^{\mathrm{T}}$ & M & Rock pool, upper littoral, Woods Hole, Mass. \\
\hline Sphingobacterium heparinum & & LMG $10339^{\mathrm{T}}$ & $T$ & Dry soil \\
\hline Sphingobacterium mizutae & & LMG $8340^{\mathrm{T}}$ & $\mathrm{T}$ & Ventricular fluid of fetus, Japan \\
\hline Sphingobacterium multivorum & & LMG $8342^{\mathrm{T}}$ & $\mathrm{T}$ & Spleen, Washington \\
\hline Sphingobacterium spiritivonum & & LMG $8347^{\mathrm{T}}$ & $T$ & Uterus, Kansas \\
\hline Sphingobacterium thalpophilum & & LMG $11520^{\mathrm{T}}$ & $\mathrm{T}$ & Wound swab, New York, N.Y. \\
\hline Spirosoma linguale & DSM $74^{\mathrm{T} e}$ & LMG $13140^{\mathrm{T}}$ & $\mathrm{N}$ & Laboratory water bath \\
\hline "[Sporocytophaga $]$ cauliformis" type 1 & & LMG 8362 & $\mathrm{~S}$ & Water, Lake Constance, Germany \\
\hline "[Sporocytophaga] cauliformis" type 2 & & LMG $8363^{\mathrm{T}}$ & $\mathrm{S}$ & Water, Lake Constance, Germany \\
\hline Sporocytophaga myxococcoides & ATCC $10010^{\mathrm{T}}$ & LMG $8393^{\mathrm{T}}$ & $\mathrm{C}$ & Soil, Quebec, Canada \\
\hline Sporocytophaga myxococcoides & DSM $1813^{e}$ & LMG 13345 & $\mathrm{C}$ & Sewage water, Germany \\
\hline "Taxeobacter gelupurpurascens" & $\mathrm{Tx} g 1^{\mathrm{Tc}}$ & LMG $13512^{\mathrm{T}}$ & $\mathrm{S}$ & Soil, Alberta, Canada \\
\hline
\end{tabular}

a ACAM, Australian Collection of Antarctic Microorganisms, University of Tasmania, Hobart, Australia; ATCC, American Type Culture Collection, Rockville, Md.; DSM, Deutsche Sammlung von Mikroorganismen, Braunschweig, Germany; JCM, Japanese Collection of Microorganisms, Tokyo, Japan; JIP, Culture Collection of the Unité de Virologie et Immunologie Moléculaires, Institut National de la Recherche Agronomique, Jouy-en-Josas, France; LMG, Culture Coilection of the Laboratorium voor Microbiologie, University of Ghent, Ghent, Belgium; NCIMB, National Collection of Industrial and Marine Bacteria, Aberdeen, United Kingdom; UASM, Soil Microbiology Laboratory, University of Alberta, Edmonton, Canada.

${ }^{b}$ Strains were grown on Dubos agar supplemented with $1 \%$ cellobiose (C), Difco marine agar 2216E (M), National Collection of Industrial and Marine Bacteria medium $81(\mathrm{~N})$, modified Shieh agar (S), or Trypticase soy agar $(\mathrm{T})$.

c Strain provided by H. Reichenbach, Gesellschaft für Biotechnologische Forschung, Braunschweig, Germany.

${ }^{d}$ Strain provided by R. P. Burchard, Department of Biological Sciences, University of Maryland, Baltimore.

${ }^{e}$ Strain provided by K. A. Malik, Deutsche Sammlung von Mikroorganismen, Braunschweig, Germany.

${ }^{f}$ Strain provided by H. Wakabayashi, Laboratory of Aquaculture Biology, Department of Fisheries, University of Tokyo, Tokyo, Japan.

${ }^{g}$ Strain provided by C. A. Mancuso, Department of Agriculture Science, University of Tasmania, Hobart, Tasmania, Australia.

${ }^{h}$ Strain provided by R. A. Holt, Department of Microbiology, Oregon State University, Corvallis.

${ }^{i}$ Strain provided by P. Rintamaki, Department of Zoology, University of Oulu, Oulu, Finland.

'Strain provided by G. H. Hansen, Department of Microbiology and Plant Physiology, University of Bergen, Bergen, Norway.

tions described above. Previously described methods were used to prepare whole-cell protein extracts, for SDS-PAGE, and to perform a numerical analysis of the scanned protein gel electropherograms with the GelCompar software package (Applied Maths, Kortrijk, Belgium) (92).

\section{RESULTS}

DNA base compositions. The DNA base compositions of the strains which we studied are shown in Table 2. Differences of 


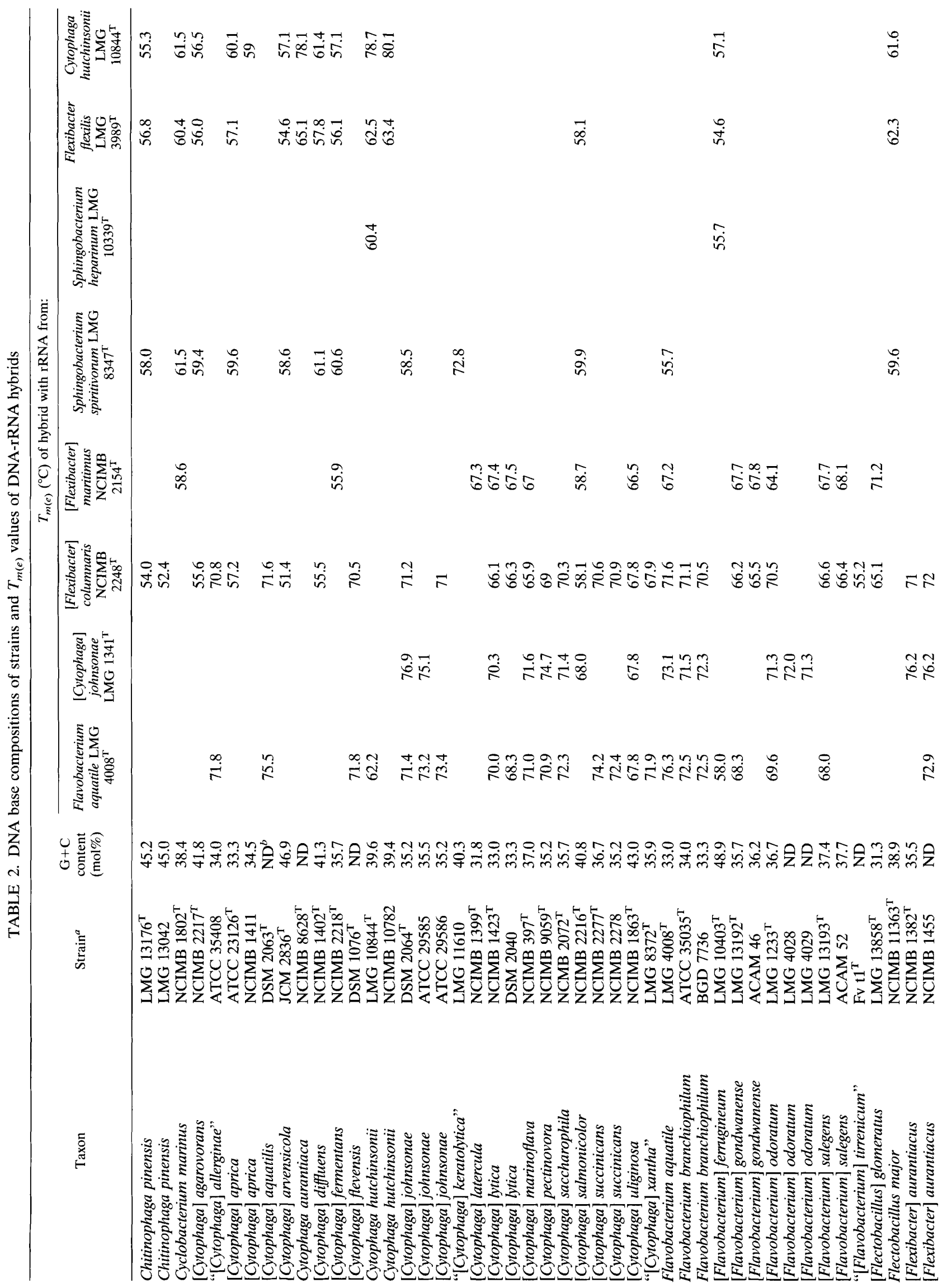




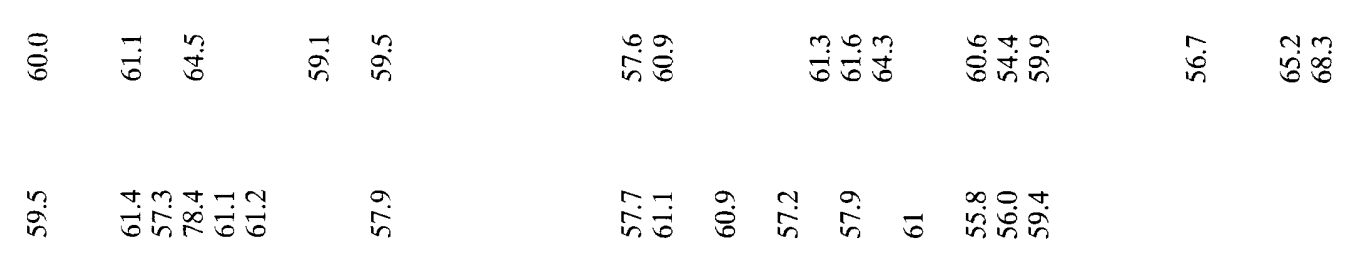

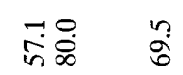

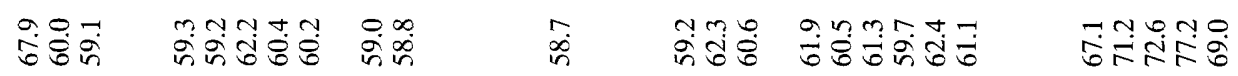

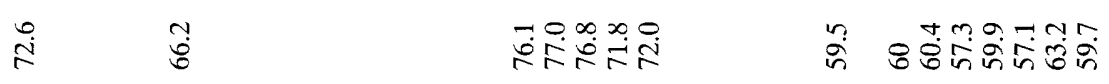

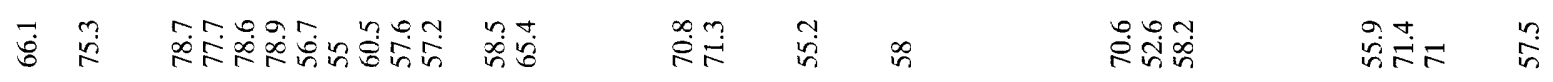

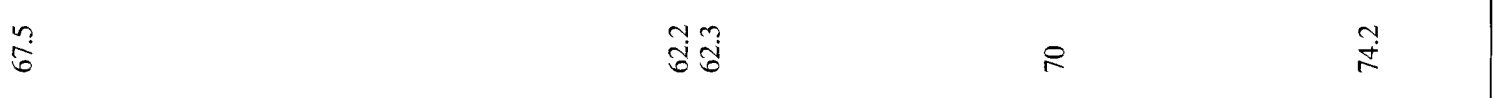

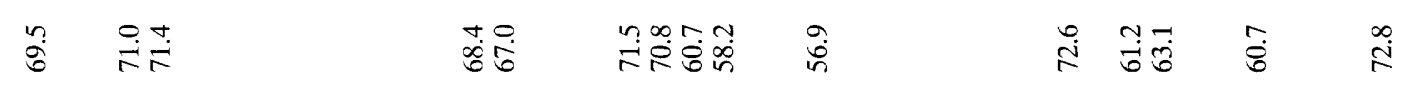

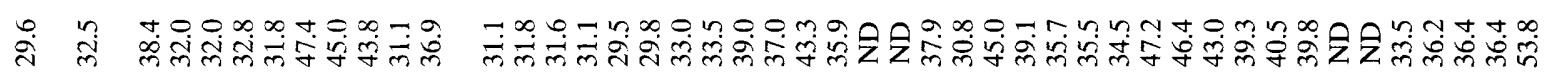

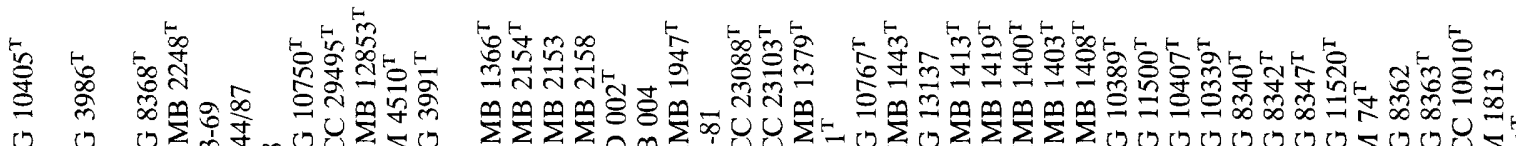

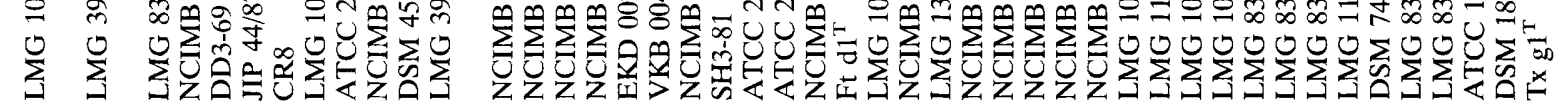

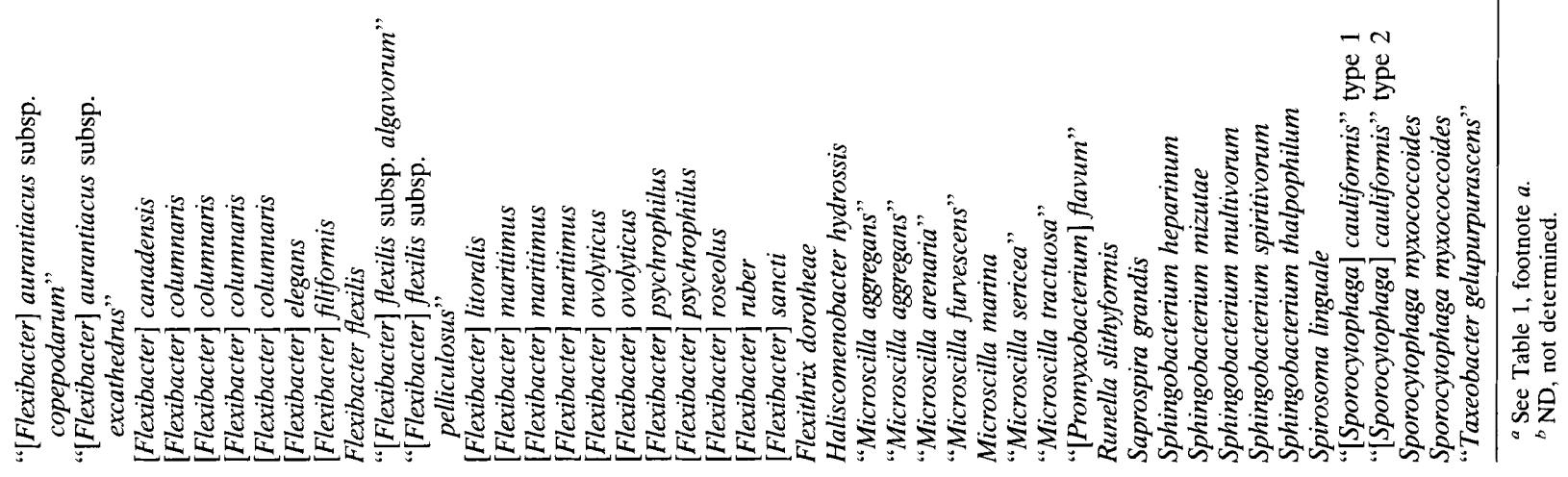




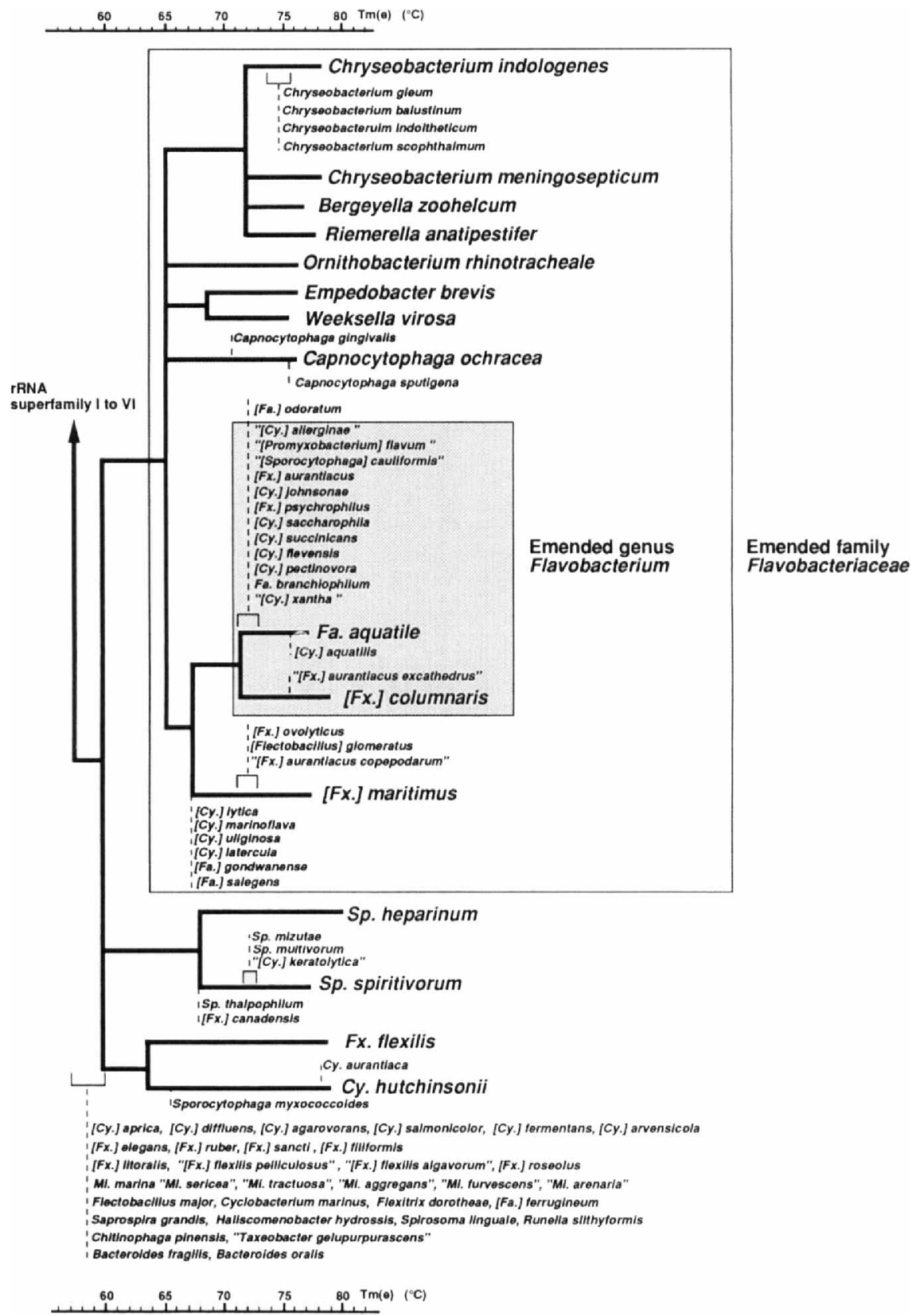

FIG. 1. Simplified rRNA cistron similarity dendrogram for rRNA superfamily V. Data from this study and references $72,73,80,85$, and 88 . Abbreviations: $F a$., Flavobacterium; Cy., Cytophaga; Fx., Flexibacter; Sp., Sphingobacterium; Mi., Microscilla.

2 to $4 \mathrm{~mol} \% \mathrm{G}+\mathrm{C}$ with previously published data $(68,71)$ were observed for the following strains: [Cytophaga] fermentans NCIMB 2218", "[Cytophaga] xantha" LMG 8372T, [Flexibacter] aurantiacus NCIMB $1382^{\mathrm{T}}$, "Taxeobacter gelupurpurascens" Txg1", and "[Sporocytophaga] cauliformis" type 1 strain LMG 8362. The greatest difference was observed with [Cytophaga] salmonicolor NCIMB $2216^{\mathrm{T}}$; the two different DNA batches which we studied had DNA G+C contents of 41 and $42 \mathrm{~mol} \%$, respectively, while the previously published value was $37 \mathrm{~mol} \%$ (68). All of other DNA base ratios determined in this study were similar to the values published previously (35, $40,48,53,68,71,95)$.

DNA-rRNA hybridization experiments. Table 2 shows the results of DNA-rRNA hybridizations between DNAs from strains belonging to the genera Flavobacterium, Cytophaga, Flexibacter, and Microscilla and related genera and radioactively labeled rRNAs from several reference strains belonging to rRNA superfamily V. These results are also shown in Fig. 1 as a dendrogram based on melting temperatures of elution $\left[T_{m(e)}\right]\left(T_{m(e)}\right.$ is the temperature at which $50 \%$ of a DNArRNA hybrid is denatured). The $T_{m(e)}$ values obtained from the reciprocal hybridization experiments performed with all of the strains belonging to each rRNA homology cluster were used to calculate the average levels of linkage between pairs of rRNA clusters. The dendrogram in Fig. 1 also includes some previously published DNA-rRNA hybridization data $(73,81$, 85,88 ).

DNA-DNA hybridization experiments. The results of the 
TABLE 3. Levels of DNA relatedness for strains of [Cytophaga] johnsonae and [Flexibacter] aurantiacus as determined by the $\mathrm{S} 1$ nuclease method at $60^{\circ} \mathrm{C}$

\begin{tabular}{|c|c|c|c|c|}
\hline \multicolumn{2}{|c|}{ Source of unlabeled DNA } & \multicolumn{3}{|c|}{ \% Reassociation with labeled DNA from: } \\
\hline Species & Strain $^{a}$ & $\begin{array}{c}\text { [Cytophaga] johnsonae } \\
\text { DSM 2064 }\end{array}$ & $\begin{array}{c}\text { [Cytophaga] johnsonae } \\
\text { ATCC } 29585\end{array}$ & $\begin{array}{c}\text { [Flexibacter] aurantiacus } \\
\text { NCIMB } 1382^{\mathrm{T}}\end{array}$ \\
\hline [Cytophaga] johnsonae & DSM $2064^{\mathrm{T}}$ & $100^{b}$ & 18 & $60,63(0.5)$ \\
\hline [Cytophaga] johnsonae & ATCC 29585 & 13 & 100 & ND \\
\hline [Cytophaga] johnsonae & ATCC 29586 & $\mathrm{ND}^{c}$ & 100 & ND \\
\hline [Cytophaga] johnsonae & NCIMB 11391 & 13 & ND & 18 \\
\hline [Flexibacter] aurantiacus & NCIMB $1382^{\mathrm{T}}$ & $64,72,60(1.2)$ & 20 & 100 \\
\hline [Flexibacter $]$ aurantiacus & NCIMB 1455 & 67,64 & 22 & 85 \\
\hline
\end{tabular}

\footnotetext{
"See Table 1, footnote $a$.

${ }^{b}$ The levels of DNA relatedness are expressed as percentages of relative binding; the results of one, two, or three experiments are shown. The values in parentheses are $\Delta T_{m}$ values (thermal stabilities of heteroduplexes) (in degrees Celsius).
}

ND, not determined.

DNA-DNA hybridization experiments performed with the [Cytophaga] johnsonae and [Flexibacter] aurantiacus strains are shown in Table 3.

FAME analysis. The fatty acid profiles of Flavobacterium aquatile and its closest phylogenetic relatives were determined, and the results of the FAME analysis are shown in Table 4. The predominant fatty acids in all of the taxa studied were 15:0, 15:0 iso, 15:0 anteiso, 15:0 iso $3 \mathrm{OH}$, summed feature 4 (15:0 iso $2 \mathrm{OH}, 16: 1 \omega 7 \mathrm{c}$, or $16: 1 \omega 7 \mathrm{t}$ or any combination of these fatty acids [Table 4]), 16:0 iso $3 \mathrm{OH}, 17: 1$ iso $\omega 9 \mathrm{c}$, and 17:0 iso $3 \mathrm{OH}$. The organisms which we studied were differentiated mainly on the basis of quantitative differences in these major fatty acids. However, some minor qualitative differences also occurred, and these differences were used to characterize several taxa. [Flexibacter] columnaris, [Flavobacterium] odoratum, and "[Flexibacter] aurantiacus subsp. excathedrus" LMG 3986 did not contain significant amounts of 15:1 $\omega 6 \mathrm{c}$ and 17:1 $\omega 6 \mathrm{c}$. In addition, [Flavobacterium] odoratum also did not contain 15:1 iso G. Flavobacterium branchiophilum strains did not contain 16:0 iso. Intraspecific heterogeneity in fatty acid contents was observed in the following four species: [Cytophaga] johnsonae, [Cytophaga] succinicans, "[Sporocytophaga] cauliformis," and [Flavobacterium] odoratum. In most cases this heterogeneity was based on quantitative differences; however, [Flavobacterium] odoratum LMG 4029 contained several fatty acids that were not detected in the two other strains of this species that were studied. When we compared our fatty acid data with data for some other taxa belonging to rRNA superfamily $\mathrm{V}$ reported previously, we found both significant similarities and diagnostic differences. The members of most taxonomic groups contained high levels of 15:0 iso and 17:0 iso $3 \mathrm{OH}$. The levels of other fatty acids varied in the different genera and species $(55,72,85,88,103)$. However, it should be noted that the cultivation conditions were different in most of the previous studies, which may have significantly affected the fatty acid compositions.

PAGE of whole-cell proteins. Figure 2 shows the protein profiles of strains belonging to the Flavobacterium aquatile rRNA cluster and the corresponding dendrogram obtained after a numerical comparison. For two species, [Flexibacter] psychrophilus and [Flexibacter] columnaris, the different strains which we studied produced very similar protein profiles, and thus these taxa could be identified easily on the basis of SDSPAGE results. In contrast, we observed intraspecific heterogeneity in the protein profiles obtained for several other species, including [Flavobacterium] odoratum, [Cytophaga] johnsonae, [Cytophaga] succinicans, and Flavobacterium branchiophilum. The last three species are discussed below. The heterogeneity of the [Flavobacterium] odoratum strains, which was suspected on the basis of the cellular fatty acid analysis results (Table 4) and the genomic differences among the strains (60), was confirmed by differences between the protein profile of [Flavobacterium] odoratum LMG 4029 and the protein profiles of the two other strains studied (LMG $1233^{\mathrm{T}}$ and LMG 4028).

\section{DISCUSSION}

Taxonomic structure of rRNA superfamily $V$. At this time, several major clusters of rRNA branches and a number of solitary taxa that have very distinct positions (e.g., the genera Ornithobacterium and Capnocytophaga) can be distinguished in rRNA superfamily $V$ on the basis of DNA-rRNA hybridization data (Fig. 1) (73, 85, 88; this study). Similar conclusions were drawn previously on the basis of $16 \mathrm{~S}$ rRNA sequence data (30, $56,101)$.

The genera Chryseobacterium (including six species previously considered Flavobacterium species [Chryseobacterium balustinum, Chryseobacterium gleum, Chryseobacterium indologenes, Chryseobacterium indoltheticum, Chryseobacterium meningosepticum, and Chryseobacterium scophthalmum]) (85), Bergeyella (including only one species, Bergeyella zoohelcum, previously considered a Weeksella species) (85), and Riemerella (including a single species, Riemerella anatipestifer, long considered a Moraxella species) (72) make up an rRNA cluster that comprises four different rRNA branches. The genera $\mathrm{Em}$ pedobacter (including only Empedobacter brevis, formerly [Flavobacterium] breve) and Weeksella (containing only one species, Weeksella virosa) (85) belong to two different rRNA branches in a second cluster. A third cluster consists of the Flavobacterium aquatile and [Flexibacter] columnaris $\mathrm{rRNA}$ branches, and 13 other taxa (most of which are generically misclassified) are located at the base level between these two rRNA branches. This last rRNA cluster is referred to as the Flavobacterium aquatile rRNA cluster and is discussed in detail below. The four members of the [Flexibacter] maritimus rRNA branch (i.e., the marine organisms "[Flexibacter] aurantiacus subsp. copepodarum," [Flexibacter] maritimus, [Flexibacter] ovolyticus, and [Flectobacillus] glomeratus) and several other marine species located at the base level between [Flexibacter] maritimus and the Flavobacterium aquatile rRNA cluster are the closest relatives of the Flavobacterium aquatile rRNA cluster. The average level of linkage between the rRNA clusters mentioned above and the solitary taxa is a $T_{m(e)}$ of $65 \pm 1.5^{\circ} \mathrm{C}$. A separate rRNA cluster is formed by the genus Sphingobacterium, in which Sphingobacterium heparinum occupies a rather distinct position $(72,73,80,81)$. Finally, Flexibacter flexilis is the only member of 
TABLE 4. Fatty acid compositions of the taxa studied ${ }^{a}$

\begin{tabular}{|c|c|c|c|c|c|c|c|c|}
\hline \multirow{2}{*}{$\operatorname{Taxon}^{b}$} & \multicolumn{8}{|c|}{$\%$ of: } \\
\hline & $\begin{array}{l}13: 0 \\
\text { iso }\end{array}$ & $\begin{array}{c}14: 0 \\
\text { iso }\end{array}$ & 15:0 & $\begin{array}{l}15: 1 \\
\omega 6 \mathrm{c}\end{array}$ & $\begin{array}{l}15: 0 \\
3 \mathrm{OH}\end{array}$ & $\begin{array}{c}15: 0 \\
\text { iso }\end{array}$ & $\begin{array}{c}15: 0 \\
\text { anteiso }\end{array}$ & $\begin{array}{l}15: 1 \\
\text { iso } G^{c}\end{array}$ \\
\hline Flavobacterium aquatile (1) & & 1.1 & 12.7 & 9.1 & 1.5 & 21.5 & 1.6 & 9.0 \\
\hline Flavobacterium branchiophilum (7) & $1.2 \pm 0.3$ & $\operatorname{tr}$ & $11.0 \pm 3.0$ & $7.6 \pm 1.6$ & $1.8 \pm 2.3$ & $22.2 \pm 3.5$ & $2.5 \pm 1.3$ & $10.9 \pm 2.2$ \\
\hline [Flexibacter] columnaris $(5)$ & $1.8 \pm 0.5$ & $\operatorname{tr}$ & $4.4 \pm 0.9$ & & $\operatorname{tr}$ & $39.0 \pm 4.0$ & $1.4 \pm 0.8$ & $13.1 \pm 1.7$ \\
\hline [Cytophaga $]$ flevensis (1) & & 2.2 & 7.6 & 8.6 & 1.6 & 14.5 & 10.4 & 5.7 \\
\hline [Cytophaga] aquatilis (1) & & 1.2 & 9.6 & 5.0 & 2.0 & 17.6 & $\operatorname{tr}$ & 3.8 \\
\hline [Cytophaga] johnsonae $(1)^{e}$ & $\operatorname{tr}$ & 1.5 & 6.1 & 1.3 & 1.2 & 24.9 & 3.4 & 4.9 \\
\hline [Cytophaga] johnsonae $(6)^{\prime}$ & & $1.3 \pm 0.7$ & $4.5 \pm 1.1$ & $3.1 \pm 0.8$ & $1.6 \pm 0.4$ & $20.1 \pm 3.0$ & $3.8 \pm 3.6$ & $5.2 \pm 1.7$ \\
\hline [Cytophaga] pectinovora (1) & & 1.2 & 6.7 & 6.4 & 2.1 & 24.1 & 2.0 & 8.0 \\
\hline [Flexibacter] psychrophilus (5) & $1.3 \pm 0.2$ & $2.0 \pm 0.7$ & $6.0 \pm 1.0$ & $5.6 \pm 0.6$ & $\operatorname{tr}$ & $19.7 \pm 1.4$ & $3.7 \pm 0.7$ & $11.7 \pm 3.5$ \\
\hline [Cytophaga] saccharophila (1) & & 1.2 & 8.5 & 7.3 & 2.5 & 9.5 & 1.3 & 6.9 \\
\hline [Cytophaga] succinicans $(2)^{g}$ & $\operatorname{tr}$ & $1.6 \pm 0.1$ & $11.8 \pm 2.1$ & $10.7 \pm 1.6$ & $3.3 \pm 1.2$ & $16.8 \pm 0.3$ & $1.1 \pm 0.7$ & $9.2 \pm 1.9$ \\
\hline [Cytophaga] succinicans $(1)^{h}$ & & $\operatorname{tr}$ & 7.6 & 6.9 & $\operatorname{tr}$ & 30.0 & 1.0 & 9.0 \\
\hline "[Cytophaga] allerginae" (1) & & & 7.9 & 2.0 & 1.4 & 27.3 & 1.2 & 3.6 \\
\hline "[Cytophaga $]$ xantha" (1) & & 3.3 & 10.9 & 11.6 & 1.9 & 9.0 & 3.9 & 3.9 \\
\hline [Flexibacter] aurantiacus (2) & $\operatorname{tr}$ & $\operatorname{tr}$ & $6.5 \pm 2.0$ & $2.4 \pm 1.4$ & $1.6 \pm 0.3$ & $29.0 \pm 3.6$ & $1.3 \pm 0.1$ & $6.9 \pm 0.6$ \\
\hline $\begin{array}{l}\text { "[Flexibacter] aurantiacus subsp. } \\
\text { excathedrus" (1) }\end{array}$ & $\operatorname{tr}$ & $\operatorname{tr}$ & 6.4 & & 2.2 & 25.6 & $\operatorname{tr}$ & 17.1 \\
\hline "[Promyxobacterium $]$ flavum" (1) & & 1.2 & 6.9 & 4.5 & 1.5 & 28.0 & 1.7 & 7.3 \\
\hline "[Sporocytophaga] cauliformis" $(1)^{i}$ & & 2.6 & 7.8 & 5.2 & 1.8 & 17.0 & 1.5 & 6.1 \\
\hline "[Sporocytophaga] cauliformis" $(1)^{j}$ & & $\operatorname{tr}$ & 8.3 & 3.3 & 2.1 & 30.0 & $\operatorname{tr}$ & 4.2 \\
\hline$\left[\right.$ Flavobacterium] odoratum $(2)^{k}$ & & & $\operatorname{tr}$ & & & $53.5 \pm 5.2$ & $1.8 \pm 1.2$ & \\
\hline [Flavobacterium] odoratum $(1)^{l}$ & 3.3 & 2.7 & 3.9 & $\operatorname{tr}$ & 1.2 & 39.0 & 1.3 & \\
\hline
\end{tabular}

${ }^{a}$ In addition, small amounts (less than $2.5 \%$ of the total fatty acids) of one or more of the following fatty acids occur in the taxa studied: unknown 11.541 (fatty acid whose identity is unknown; the number indicates the equivalent chain length), unknown 13.566 , unknown 16.580, 14:0, 15:0 2OH, 16:1 $\omega 5 \mathrm{c}, 16: 1$ iso $\mathrm{G}, 17: 1 \omega 8 \mathrm{c}, 17: 0$ $3 \mathrm{OH}, 18: 1 \omega 5 \mathrm{c}$, summed feature $3(14: 03 \mathrm{OH}$ or 16:1 iso I or both), and summed feature $5(17: 1$ iso I or 17:1 anteiso B or both).

${ }^{b}$ The numbers in parentheses are the numbers of strains studied. Unless indicated otherwise below, the strains used were the strains shown in Table 1 . When two or more strains were used, the mean \pm standard deviation is shown.

${ }^{c}$ The double bound position indicated by the capital letter is not known.

${ }^{d}$ The fatty acids $15: 0$ iso $2 \mathrm{OH}, 16: 1 \omega 7 \mathrm{c}$, and 16:1 $\omega 7 \mathrm{t}$ could not be separated from each other by gas chromatography by using the Microbial Identification System (Microbial ID, Inc., Newark, Del.) software package and together were considered summed feature 4.

e [Cytophaga] johnsonae DSM 2064 ${ }^{\mathrm{T}}$.

${ }^{f}$ All of the [Cytophaga] johnsonae strains in Table 1 except DSM $2064^{\mathrm{T}}$.

$g$ [Cytophaga] succinicans NCIMB $2277^{\mathrm{T}}$ and NCIMB 2279.

" [Cytophaga] succinicans NCIMB 2278.

i "[Sporocytophaga] cauliformis" LMG 8362.

"[Sporocytophaga] cauliformis" LMG $8363^{\mathrm{T}}$

${ }^{k}$ [Flavobacterium] odoratum LMG $1233^{\mathrm{T}}$ and LMG 4028.

' [Flavobacterium] odoratum LMG 4029.

its rRNA branch, whereas the cellulolytic organisms (Cytophaga hutchinsonii, Cytophaga aurantiaca, and Sporocytophaga myxococcoides) make up the Cytophaga hutchinsonii rRNA branch. The Sphingobacterium rRNA cluster and the Cytophaga hutchinsonii and Flexibacter flexilis rRNA branches are linked to each other and to the other rRNA clusters in superfamily $\mathrm{V}$ at a $T_{m(e)}$ of $60 \pm 2.0^{\circ} \mathrm{C}$.

Several organisms, most of which are represented by a single strain, do not belong to any of the rRNA clusters described above. With average $T_{m(e)}$ values less than $60^{\circ} \mathrm{C}$, the following organisms occupy peripheral positions on the $T_{m(e)}$ dendrogram: Bacteroides fragilis and Bacteroides oralis (88); Chitinophaga pinensis; Cyclobacterium marinus (formerly [Flectobacillus] marinus) (67); [Cytophaga] agarovorans; [Cytophaga] aprica; [Cytophaga] arvensicola; [Cytophaga] diffluens; [Cytophaga] fermentans; [Cytophaga] salmonicolor; [Flavobacterium] ferrugineum; Flectobacillus major; [Flexibacter] elegans; [Flexibacter] filiformis; "[Flexibacter] flexilis subsp. algavonum"; "[Flexibacter] flexilis subsp. pelliculosus"; [Flexibacter] litoralis; [Flexibacter] roseolus; [Flexibacter] ruber; [Flexibacter] sancti; Flexithrix dorotheae; Haliscomenobacter hydrossis; "[Microscilla] aggregans"; "[Microscilla] arenaria"; "[Microscilla] furvescens"; [Microscilla] marina; "[Microscilla] sericea"; "[Microscilla] tractuosa"; Runella slithyformis; Saprospira grandis; Spirosoma linguale; and "Taxeobacter gelupurpurascens." rRNA sequencing is a better method than DNA-rRNA hybridization for revealing deep phylogenetic relationships (97), and recent data obtained by the former technique have indeed indicated that most of these taxa should be assigned to the Cytophaga-Flavobacterium-Bacteroides group $(30,56,58,98,101)$. Two marine facultatively anaerobic species, [Cytophaga] agarovorans and [Cytophaga] salmonicolor, have recently been reclassified in the new genus "Marinolabilia" (57). "[Flavobacterium] tirrenicum" is probably not related to superfamily $\mathrm{V}$, as demonstrated by its very low level of rRNA homology (Table 2) and its quite different polyamine distribution (34), but at this time no rRNA sequence is available to determine the phylogenetic relationships of this organism.

For technical reasons, the following species were not included in this study: [Cytophaga] xylanolytica, [Flexibacter] polymorphus, Sphingobacterium antarcticus, Sphingobacterium faecium, Sphingobacterium piscium, "Taxeobacter ocellatus," and "Taxeobacter chitinovorans." rRNA sequencing data have revealed that [Cytophaga] xylanolytica and [Flexibacter] polymorphus belong to the Cytophaga-Flavobacterium-Bacteroides group $(32,58)$. The three new Sphingobacterium species mentioned above have been clearly identified as members of this genus on the basis of chemotaxonomic data and DNA-DNA hybridization data $(74,83,84)$. No rRNA sequences have been published yet for members of the recently proposed genus 
TABLE 4-Continued

\begin{tabular}{|c|c|c|c|c|c|c|c|c|c|}
\hline \multicolumn{10}{|c|}{$\%$ of: } \\
\hline $\begin{array}{c}15: 0 \\
\text { iso } 30 \mathrm{OH}\end{array}$ & $16: 0$ & $\begin{array}{l}\text { Summed } \\
\text { feature } 4^{d}\end{array}$ & $\begin{array}{l}16: 0 \\
3 \mathrm{OH}\end{array}$ & $\begin{array}{l}16: 0 \\
\text { iso }\end{array}$ & $\begin{array}{c}16: 0 \\
\text { iso } 3 \mathrm{OH}\end{array}$ & $\begin{array}{c}16: 1 \\
\text { iso } \mathrm{H}\end{array}$ & $\begin{array}{l}17: 1 \\
\omega 6 c\end{array}$ & $\begin{array}{c}17: 1 \\
\text { iso } \omega 9 \mathrm{c}\end{array}$ & $\begin{array}{c}17: 0 \\
\text { iso } 3 \mathrm{OH}\end{array}$ \\
\hline 6.6 & $\operatorname{tr}$ & 4.0 & $\operatorname{tr}$ & 2.4 & 5.1 & 2.2 & 4.1 & 4.8 & 7.4 \\
\hline $14.3 \pm 2.7$ & $1.1 \pm 0.3$ & $4.5 \pm 1.9$ & $2.3 \pm 0.6$ & & $1.7 \pm 0.6$ & $\operatorname{tr}$ & $5.1 \pm 1.2$ & $\operatorname{tr}$ & $5.7 \pm 0.8$ \\
\hline $8.7 \pm 2.5$ & $\operatorname{tr}$ & $\operatorname{tr}$ & tr & $2.0 \pm 1.2$ & $2.6 \pm 1.0$ & $\operatorname{tr}$ & & $7.5 \pm 1.6$ & $12.1 \pm 1.3$ \\
\hline 4.9 & 1.4 & 18.4 & 4.1 & 1.4 & 3.8 & & 2.7 & $\operatorname{tr}$ & 3.9 \\
\hline 8.9 & 1.3 & 13.4 & 4.5 & 2.0 & 6.8 & 1.4 & 4.1 & 2.5 & 8.3 \\
\hline 6.6 & 2.7 & 12.8 & 4.7 & 3.4 & 4.4 & & 2.2 & 2.4 & 9.4 \\
\hline $8.8 \pm 1.7$ & $1.6 \pm 0.5$ & $18.2 \pm 1.6$ & $3.7 \pm 1.2$ & $1.3 \pm 0.5$ & $4.7 \pm 2.0$ & $\mathrm{tr}$ & $2.8 \pm 0.7$ & $2.7 \pm 0.7$ & $9.6 \pm 1.3$ \\
\hline 7.9 & $\operatorname{tr}$ & 5.3 & tr & 1.5 & 4.7 & $\mathrm{tr}$ & 5.2 & 5.1 & 12.1 \\
\hline $8.5 \pm 2.2$ & $\operatorname{tr}$ & $2.3 \pm 0.5$ & & $2.5 \pm 1.0$ & $3.3 \pm 1.0$ & $4.2 \pm 1.8$ & $2.2 \pm 0.6$ & $12.2 \pm 1.4$ & $9.0 \pm 2.2$ \\
\hline 5.9 & $\mathrm{tr}$ & 12.3 & 1.4 & 3.7 & 5.3 & 2.0 & 7.6 & 5.6 & 9.6 \\
\hline $8.6 \pm 3.7$ & $\operatorname{tr}$ & $7.5 \pm 6.3$ & $2.2 \pm 0.5$ & $1.3 \pm 0.5$ & $4.5 \pm 1.3$ & $1.8 \pm 1.0$ & $4.0 \pm 1.0$ & $2.4 \pm 1.7$ & $5.8 \pm 0.5$ \\
\hline 10.7 & $\operatorname{tr}$ & 5.8 & 1.7 & 1.9 & 3.3 & 1.7 & 3.1 & 3.3 & 7.8 \\
\hline 6.7 & 3.0 & 14.5 & 4.5 & 1.5 & 3.2 & & 2.2 & 3.1 & 8.7 \\
\hline 5.2 & 1.0 & 5.0 & 1.4 & 4.1 & 9.6 & 2.6 & 12.5 & 2.1 & 6.2 \\
\hline 7.5 & & 5.4 & tr & 1.9 & 4.3 & & tr & 7.4 & 12.6 \\
\hline 8.7 & $\operatorname{tr}$ & 6.6 & $\mathrm{tr}$ & 2.3 & 3.1 & 1.1 & 3.5 & 3.7 & 13.6 \\
\hline 7.9 & 1.1 & 11.8 & 3.2 & 4.7 & 8.2 & 2.1 & 3.2 & 2.5 & 7.9 \\
\hline 8.7 & 1.4 & 12.4 & 5.1 & 1.2 & 4.1 & & 2.1 & 2.3 & 7.7 \\
\hline $5.7 \pm 1.6$ & $\operatorname{tr}$ & $1.6 \pm 2.3$ & $3.5 \pm 1.5$ & $1.4 \pm 0.5$ & $\operatorname{tr}$ & & & $13.5 \pm 2.9$ & $12.8 \pm 2.8$ \\
\hline 4.0 & $\mathrm{tr}$ & 8.3 & 5.4 & 4.4 & 2.1 & 1.9 & tr & 8.3 & 8.6 \\
\hline
\end{tabular}

"Taxeobacter" (71), but an oligonucleotide cataloging study revealed that a "Taxeobacter ocellatus" strain is relatively closely related to Sphingobacterium heparinum (63). In this study, we observed only low levels of rRNA homology between "Taxeobacter gelupurpurascens" and the rRNA probes tested (Table 2).

Genera Cytophaga and Flexibacter. Our DNA-rRNA hybridization data clearly show that the genera Cytophaga and Flexibacter (as presently defined) are polyphyletic and thus confirm and extend similar conclusions based on previous DNA-rRNA hybridization results and on $16 \mathrm{~S}$ rRNA sequence comparisons $(6,30,45,46,56,58,72,73,85,101)$. The genus names $C y$ tophaga and Flexibacter must be preserved for members of the Cytophaga hutchinsonii and Flexibacter flexilis rRNA branches, respectively. Other Cytophaga and Flexibacter species, which belong to several rRNA branches and clusters in rRNA superfamily $\mathrm{V}$ or occupy peripheral positions on the $T_{m(e)}$ dendrogram, must be considered generically misclassified (Fig. 1). As the type species of the genus Flexibacter, Flexibacter flexilis, is the only member of its rRNA branch, the genus Flexibacter is restricted to this species. All other Flexibacter species should be reclassified. In the case of the genus Cytophaga, the type species (Cytophaga hutchinsonii) and Cytophaga aurantiaca are the only genuine Cytophaga species, and the members of the cellulolytic microcyst-forming genus Sporocytophaga (Sporocytophaga myxococcoides is the type and only valid species) are their closest relatives. The difference in $T_{m(e)}$ between Sporocytophaga myxococcoides and Cytophaga hutchinsonii $\left(13.5^{\circ} \mathrm{C}\right)$ is great enough to justify separate generic status for the former taxon. The cellulolytic Cytophaga species can also be clearly differentiated from the other Cytophaga and Flexibacter species on the basis of their sulfonolipid contents (26). All other $C y$ tophaga species (i.e., noncellulolytic Cytophaga species) should be reclassified. Such a restriction of the genera Cytophaga and Flexibacter to the type species and some close phylogenetic relatives was suggested previously on the basis of $16 \mathrm{~S}$ rRNA sequence data $(56,70)$.

As shown by DNA-rRNA hybridization data, several gener- ically misclassified Cytophaga and Flexibacter species are located in the Sphingobacterium rRNA cluster (Fig. 1). The generic status of Sphingobacterium heparinum has been discussed repeatedly, and transfers of this organism to other or new genera have been proposed $(16,68,80,84)$; however, the specific status of Sphingobacterium heparinum has now been established on the basis of genomic data (80). The results of rRNA homology experiments also confirmed that all Sphingobacterium species belong to a single rRNA branch (72). These findings corroborate the proposals of Takeuchi and Yokota $(83,84)$, who included [Flavobacterium] yabuuchiae in Sphingobacterium spiritivorum and [Cytophaga] keratolytica in Sphingobacterium multivonum. [Flexibacter] canadensis is also a peripheral member of this cluster, a position confirmed by the 16S rRNA sequence of this organism (56). Because Sphingobacterium thalpophilum (formerly [Flavobacterium] thalpophilum) was found to contain sphingophospholipids, transfer of this species to the genus Sphingobacterium was proposed (19, 84). As [Flexibacter] canadensis occurs at the same position on the dendrogram as Sphingobacterium thalpophilum, the results of lipid content analyses and the possible presence of sphingophospholipids may be decisive in transferring [Flexibacter] canadensis to the genus Sphingobacterium or in creating a new genus to accommodate this species.

The [Flexibacter] maritimus rRNA branch includes several species that were isolated from marine environments and are generically misclassified. One of these is [Flectobacillus] glomeratus, since the type species of the genus Flectobacillus, Flectobacillus major, is located at a rather low level on the Cytophaga hutchinsonii rRNA branch as determined by $16 \mathrm{~S}$ rRNA sequence data (24). Additional data will be necessary to determine the generic relationships of members of the [Flexibacter] maritimus rRNA branch, the Flavobacterium aquatile rRNA cluster, and the peripherally related taxa [Cytophaga] latercula, [Cytophaga] lytica, [Cytophaga] marinoflava, [Cytophaga] uliginosa, [Flavobacterium] gondwanense, and [Flavobacterium] salegens (Fig. 1). The great genomic heterogene- 


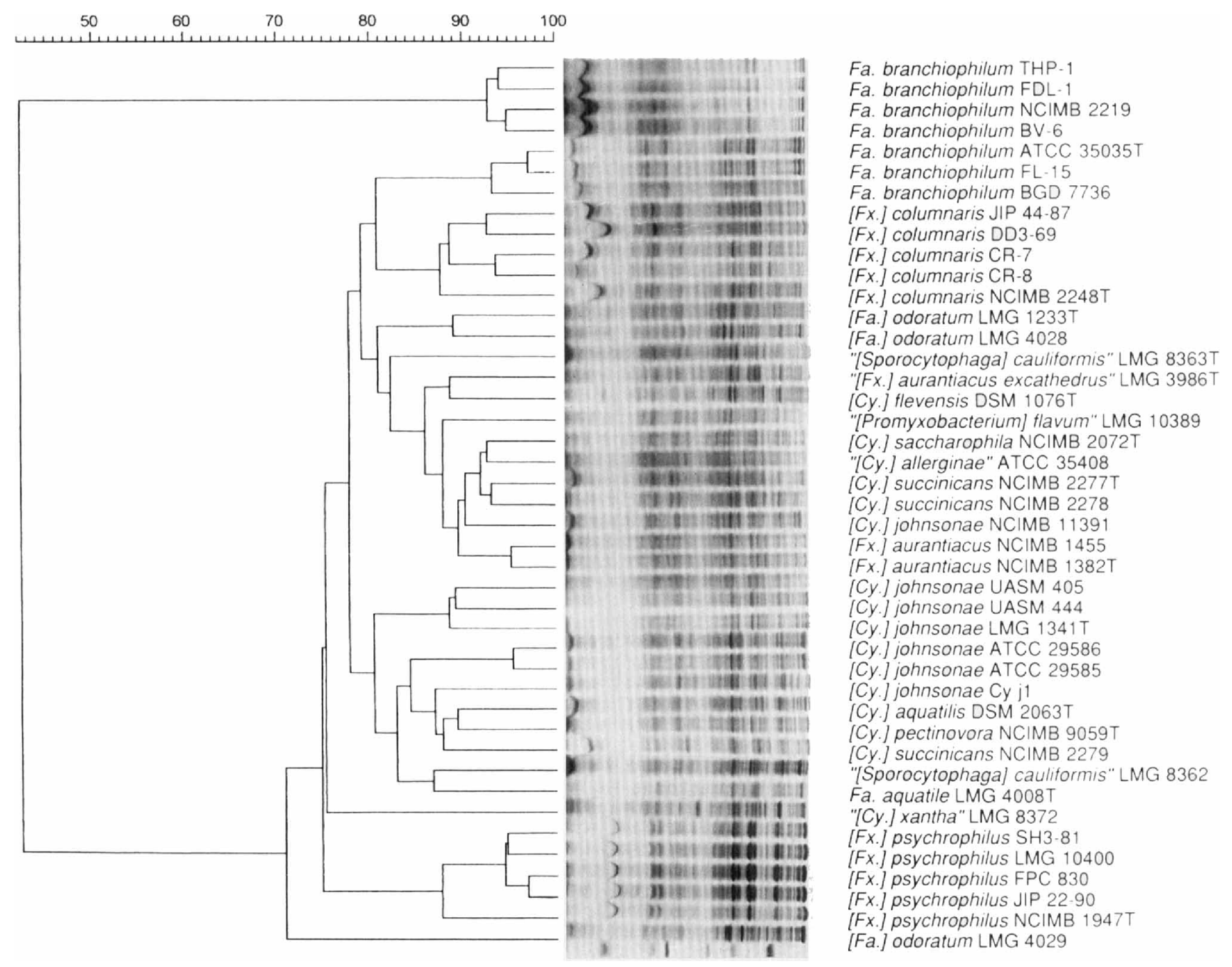

FIG. 2. Electrophoretic protein profiles and corresponding dendrogram for all of the strains studied in the Flavobacterium aquatile rRNA cluster. The dendrogram was constructed by using unweighted pair group average linkage of the correlation coefficients for pairs of protein patterns. The molecular weight markers used (indicated at the bottom) were (from left to right) trypsin inhibitor (molecular weight, 20,100), trypsinogen $(24,000)$, carbonic anhydrase $(29,000)$, glyceraldehyde-3phosphate dehydrogenase $(36,000)$, egg albumin $(45,000)$, and bovine albumin $(66,000)$. For abbreviations see the legend to Fig. 1 .

ity in the [Flexibacter] maritimus rRNA branch was also revealed by $16 \mathrm{~S}$ rRNA sequence data $(24,30,56,88)$.

Genus Flavobacterium. Since several species previously included in the genus Flavobacterium have been reclassified as members of new or other genera, at this time the only valid Flavobacterium species are Flavobacterium aquatile (the type species), Flavobacterium branchiophilum, [Flavobacterium $]$ ferrugineum, [Flavobacterium] gondwanense, [Flavobacterium] odoratum, and [Flavobacterium] salegens $(24,40,85,95)$. The large differences in $T_{m(e)}$ between [Flavobacterium] ferrugineum, [Flavobacterium] gondwanense, or [Flavobacterium] salegens and Flavobacterium aquatile (Table 2 and Fig. 1) demonstrate that [Flavobacterium] ferrugineum, [Flavobacterium] gondwanense, and [Flavobacterium] salegens do not belong to the genus Flavobacterium and should be reclassified. In contrast, phenotypic similarities and low differences in $T_{m(e)}$ between Flavobacterium branchiophilum and Flavobacterium aquatile support inclusion of Flavobacterium branchiophilum in the genus Flavobacterium. [Flavobacterium] odoratum, several misclassified Cytophaga and Flexibacter species, "[Promyxobacterium ] flavum," and "[Sporocytophaga] cauliformis" all form a single rRNA homology cluster. So far, this cluster includes two rRNA branches; one of these branches includes [Flexibacter] columnaris and "[Flexibacter] aurantiacus subsp. excathedrus," and the other is composed of Flavobacterium aquatile and [Cytophaga] aquatilis. All other species ([Flavobacterium] odoratum, "[Cytophaga] allerginae," [Cytophaga] flevensis, [Cytophaga] johnsonae, [Cytophaga] pectinovora, [Cytophaga] saccharophila, [Cytophaga] succinicans, "[Cytophaga] xantha," Flavobacterium branchiophilum, [Flexibacter] aurantiacus, [Flexibacter] psychrophilus, "[Promyxobacterium $]$ flavum," and "[Sporocytophaga] cauliformis") are located at the base level between the two branches (Table 2 and Fig. 1). The range of levels of genomic divergence in this rRNA cluster is rather wide, corresponding to a difference in $T_{m(e)}$ of about $8^{\circ} \mathrm{C}$, although several other genera, such as the genus Sphingobacterium (72), have similar levels of genomic divergence. In such cases, all species belonging to the rRNA cluster can be placed in one genus or several genera can be created, depending on the phenotypic characteristics of the species $(22,85)$.

Besides their similar habitats (soil or freshwater or both) most of the taxa included in this rRNA cluster have a consid- 
erable number of characteristics in common. They contain menaquinone 6 as the major respiratory quinone $(56,61)$; their $\mathrm{G}+\mathrm{C}$ contents are in the range from 32 to $37 \mathrm{~mol} \%$ (Table 1 ) $(40,68)$; they exhibit clear gliding motility (a possible exception is Flavobacterium branchiophilum, but the motility of this organism may have been overlooked, as the motility of Flavobacterium aquatile was for a long time); they produce yellow nondiffusible pigments; and they have many classical phenotypic characteristics in common (see below). In addition, the metabolism of most of these organisms is strictly aerobic (the exceptions are [Cytophaga] aquatilis and [Cytophaga] succinicans, which can also grow anaerobically when some growth factors are provided [68]). Finally, these organisms have very similar fatty acid profiles (see below) (Table 4). [Flavobacterium] odoratum can be easily distinguished from the other members of the cluster by its clinical origin, its lack of gliding motility, its good growth at $37^{\circ} \mathrm{C}$, its halotolerance $(10,41,61)$, and several differences in its fatty acid profile (Table 4 ).

Therefore, both phenotypic and genotypic criteria justify inclusion of most of the members of the Flavobacterium aquatile rRNA cluster in a separate genus; the only exception is [Flavobacterium] odoratum. This conclusion is supported by 16S rRNA sequence data; the soil and freshwater organisms cluster on a separate branch, while [Flavobacterium] odoratum occupies a clearly independent position $(30,56,57)$. Moreover, researchers have found small-subunit rRNA sequence signatures which clearly differentiate [Flavobacterium] odoratum from its neighbors (30). Therefore, we propose that Flavobacterium aquatile should be the type species of an emended genus Flavobacterium and that all valid taxa isolated from soil and freshwater belonging to the Flavobacterium aquatile rRNA cluster should be placed in the emended genus Flavobacterium. Below, we present an emended description of the genus Flavobacterium and propose new combinations for seven of its members.

There is a nomenclatural problem concerning [Cytophaga] aquatilis. This valid species (82), which at this time is represented by only one available strain, is indeed an independent taxon, as demonstrated by DNA-DNA homology data. The DNA of this organism does not exhibit significant levels of homology with DNAs from Flavobacterium aquatile and several other members of the Flavobacterium aquatile rRNA cluster (9). The fatty acid and protein profiles of [Cytophaga] aquatilis are also clearly different from the profiles of the other organisms (see below) (Table 4 and Fig. 2). If the combination [Cytophaga] aquatilis (Strohl and Tait 1978) was modified in a way that was consistent with its new generic status, it would become a junior homonym of Flavobacterium aquatile (Frankland and Frankland 1889). Therefore, below we propose a new name for this taxon, Flavobacterium hydatis, on the basis of Rule $12 \mathrm{~b}$ of the International Code of Nomenclature of Bacteria (47a). The new specific epithet was chosen because its meaning is similar to that of the former epithet.

The specific epithet of [Cytophaga] johnsonae is another problem, as this epithet was incorrectly formed by Stanier in 1947 (78). In 1957 Stanier changed the epithet to johnsonii, which is also incorrect (79). As this epithet was created in honor of the American microbiologist Delia E. Johnson, who first isolated this species, it should be a genitive noun with a feminine ending. Therefore, we propose that the new name for this organism should be as Flavobacterium johnsoniae.

Other problems concern the taxonomic status of the valid species [Flexibacter] aurantiacus and the invalid taxa "[Cytophaga] allerginae," "[Cytophaga] xantha," "[Flexibacter] aurantiacus subsp. excathedrus," "[Promyxobacterium] flavum," and "[Sporocytophaga] cauliformis." We propose that [Flexibacter] aurantiacus strains should be included in [Cytophaga] johnsonae and that all of the invalid taxa should be referred to as Flavobacterium sp. (see below).

Consequently, the emended genus Flavobacterium contains the following species: Flavobacterium aquatile, Flavobacterium branchiophilum, Flavobacterium columnare, Flavobacterium flevense, Flavobacterium hydatis, Flavobacterium johnsoniae, Flavobacterium pectinovorum, Flavobacterium psychrophilum, Flavobacterium saccharophilum, and Flavobacterium succinicans. All other Flavobacterium species are generically misclassified.

Emended description of the genus Flavobacterium Bergey, Harrison, Breed, Hammer, and Huntoon 1923. Cells are rods with parallel or slightly irregular sides and rounded or slightly tapered ends and usually are 2 to $5 \mu \mathrm{m}$ long and 0.3 to $0.5 \mu \mathrm{m}$ wide. Under certain growth conditions, some species may also produce shorter $(1-\mu \mathrm{m})$ or longer $(10-$ to $40-\mu \mathrm{m})$ filamentous cells. The longer rods are flexible. Motile by gliding (this characteristic has not been observed in Flavobacterium branchiophilum). Flagella are absent. Gram negative. Resting stages are not known. Intracellular granules of poly- $\beta$-hydroxybutyrate are absent. Colonies are circular, convex or low convex, and shiny with entire or wavy edges (sometimes sunken into the agar) on solid media containing high nutrient contents. On solid media containing low levels of nutrients most species also produce flat or very thin, spreading, sometimes very adherent swarms with uneven, rhizoid, or filamentous margins. Colonies are typically yellow (they vary from cream to bright orange) because of nondiffusible carotenoid or flexirubin types of pigments or both, but nonpigmented strains do occur. Most species do not grow on seawater-containing media; an exception to this is Flavobacterium flevense. Most species are able to grow on nutrient agar and on Trypticase soy agar. Chemoorganotrophic. Aerobic with a respiratory type of metabolism. When certain growth factors are provided, Flavobacterium hydatis and Flavobacterium succinicans also grow anaerobically $(4,14$, 68,82 ). Peptones are used as nitrogen sources, and $\mathrm{NH}_{3}$ is released from peptones; growth occurs on peptone alone. Acid is produced from carbohydrates by all species except Flavobacterium columnare and Flavobacterium psychrophilum. All species except Flavobacterium flevense decompose gelatin and casein, and several species also hydrolyze various polysaccharides, including starch, chitin, pectin, and carboxymethyl cellulose. Flavobacterium flevense and Flavobacterium saccharophilum are also agarolytic. Cellulose is never decomposed. Tributyrin and Tween compounds are decomposed. Indole is not produced. Catalase is produced. Cytochrome oxidase is produced by all species except Flavobacterium saccharophilum.

Menaquinone 6 is the only respiratory quinone. The predominant fatty acids are 15:0, 15:0 iso, 15:1 iso $\mathrm{G}, 15: 0$ iso $3 \mathrm{OH}$, summed feature $4(15: 0$ iso $2 \mathrm{OH}, 16: 1 \omega 7 \mathrm{c}$, or $16: 1 \omega 7 \mathrm{t}$ or any combination of these fatty acids), 16:0 iso $3 \mathrm{OH}, 17: 1$ iso $\omega 9 \mathrm{c}$, and 17:0 iso $3 \mathrm{OH}$. Sphingophospholipids are absent. Homospermidine is the major polyamine in all 10 Flavobacterium species; all species except Flavobacterium branchiophilum and Flavobacterium saccharophilum also contain putrescine as a minor component $(33,34)$. Spermidine and spermine are also minor components in Flavobacterium branchiophilum, while Flavobacterium johnsoniae is the only member of the genus that contains minor amounts of agmatine and 2-hydroxyputrescine (34). The optimum temperature range for most species is 20 to $30^{\circ} \mathrm{C}$; the optimum temperature range for Flavobacterium psychrophilum is 15 to $18^{\circ} \mathrm{C}$.

These organisms are widely distributed in soil and freshwater habitats, where they decompose organic matter. Several species are pathogenic for freshwater fish (Flavobacterium 
TABLE 5. Phenotypic characteristics that can be used to differentiate the 10 valid species belonging to the genus Flavobacterium ${ }^{a}$

\begin{tabular}{|c|c|c|c|c|}
\hline Characteristic & Flavobacterium aquatile & $\begin{array}{l}\text { Flavobacterium } \\
\text { branchiophilum }\end{array}$ & $\begin{array}{l}\text { Flavobacterium } \\
\text { columnare }\end{array}$ & $\begin{array}{l}\text { Flavobacterium } \\
\text { flevense }\end{array}$ \\
\hline Morphology of colonies on $\mathrm{AOA}^{b}$ & $\begin{array}{l}\text { Low convex, round, with } \\
\text { entire margins }\end{array}$ & $\begin{array}{l}\text { Low convex, round, with } \\
\text { entire margins }\end{array}$ & $\begin{array}{l}\text { Flat, rhizoid, strongly } \\
\text { adherent to agar }\end{array}$ & $\begin{array}{l}\text { Low convex, round, } \\
\text { sunken into agar }\end{array}$ \\
\hline Congo red absorption ${ }^{c}$ & $-{ }^{d}$ & - & + & - \\
\hline Growth on seawater media & - & - & - & + \\
\hline Growth on nutrient agar & - & - & - & + \\
\hline Growth on Trypticase soy agar & $(+)$ & - & - & t \\
\hline Gliding motility & $t^{e}$ & - & + & + \\
\hline Flexirubin type of pigments ${ }^{f}$ & - & - & + & - \\
\hline $\begin{array}{l}\text { Glucose used as a sole carbon } \\
\text { and energy source }\end{array}$ & ND & ND & - & + \\
\hline $\begin{array}{l}\text { Acid produced aerobically from } \\
\text { carbohydrates }\end{array}$ & + & + & - & + \\
\hline \multicolumn{5}{|l|}{ Degradation of: } \\
\hline Gelatin & V & + & + & - \\
\hline Casein & + & + & + & - \\
\hline Starch & $\mathrm{V}$ & + & - & $\mathrm{V}$ \\
\hline Carboxymethyl cellulose & - & - & - & - \\
\hline Agar & - & - & - & + \\
\hline Alginate & ND & ND & ND & - \\
\hline Pectin & ND & ND & ND & + \\
\hline Chitin & - & - & - & - \\
\hline Esculin & V & - & - & + \\
\hline DNA & - & - & + & - \\
\hline Tyrosine & $\mathrm{V}$ & + & - & - \\
\hline $\begin{array}{l}\text { Brown diffusible pigment } \\
\text { produced on tyrosine agar }\end{array}$ & - & - & $\mathrm{v}$ & - \\
\hline $\begin{array}{l}\text { Precipitate formed on egg yolk } \\
\text { agar }\end{array}$ & + & + & + & - \\
\hline$\beta$-Galactosidase activity ${ }^{g}$ & $\mathrm{~V}$ & + & - & + \\
\hline $\begin{array}{l}\text { Susceptibility to vibriostatic } \\
\text { compound } \mathrm{O} / 129^{/ 2}\end{array}$ & - & + & + & + \\
\hline $\mathrm{H}_{2} \mathrm{~S}$ production & - & - & + & - \\
\hline Production of cytochrome oxidase & + & + & + & + \\
\hline Nitrate reduction & $\mathrm{V}$ & - & $\mathrm{V}$ & V \\
\hline
\end{tabular}

${ }^{a}$ Data from references $1,4,8-10,13,15,16,40,61,68,82,90$, and 95 .

${ }^{b}$ AOA, Anacker-Ordal agar (0.05\% tryptone, $0.05 \%$ yeast extract, $0.02 \%$ beef extract, $0.02 \%$ sodium acetate) (3).

${ }^{c}$ Production of an extracellular galactosamin glycan was revealed by flooding the colonies with a $0.01 \%$ aqueous solution of Congo red (52).

$d+$, all strains are positive; - , all strains are negative; $(+)$, weakly positive; $\mathrm{v}$, variable among strains; $\mathrm{V}$, variable among references; ND, no data available.

' Gliding motility was observed in the type and only strain of Flavobacterium aquatile under certain conditions (39).

$f$ The presence of the flexirubin type of pigments was revealed by a distinct, reversible color shift of the colonies when they were flooded with a $20 \%$ (wt/vol) $\mathrm{KOH}$ aqueous solution (28).

$g$ Determined by the $o$-nitrophenyl- $\beta$-D-galactopyranoside test.

${ }^{h}$ Determined by a diffusion method in which $500-\mu \mathrm{g}$ disks were used.

branchiophilum, Flavobacterium columnare, Flavobacterium psychrophilum) or occasionally are isolated from diseased freshwater fish (Flavobacterium hydatis, Flavobacterium johnsoniae, Flavobacterium succinicans). The $\mathrm{G}+\mathrm{C}$ contents of the DNAs are 32 to $37 \mathrm{~mol} \%$. The type species is Flavobacterium aquatile (Frankland and Frankland 1889) Bergey, Harrison, Breed, Hammer, and Huntoon 1923.

Description of Flavobacterium aquatile (Frankland and Frankland 1889) Bergey, Harrison, Breed, Hammer, and Huntoon 1923. The description of Flavobacterium aquatile is the same as that given previously (40), with the following additions and modifications: no flexirubin type of pigment is produced; peptones are used as nitrogen sources, but urea and Casamino Acids are not; gelatin, tyrosine, starch, esculin, tributyrin, and lecithin are degraded, but carboxymethyl cellulose, agar, and chitin are not; nitrate is reduced; and $o$-nitrophenyl$\beta$-D-galactopyranoside is hydrolyzed $(10,15,61)$.

Description of Flavobacterium branchiophilum Wakabayashi, Huh, and Kimura 1989. Flavobacterium branchiophilum was originally described as Flavobacterium branchiophila (95), but the specific epithet was later corrected (94). The description of this taxon is the same as that given previously (95), with the following additions: tyrosine, tributyrin, lecithin, and Tween compounds are degraded, but carboxymethyl cellulose is not; hydrogen sulfide is not produced; $o$-nitrophenyl- $\beta$-D-galactopyranoside is hydrolyzed; and no growth occurs at $37^{\circ} \mathrm{C}(9)$. This species is frequently isolated from diseased gills of fish, and pathogenicity for fish has been demonstrated by experimental infection tests (95).

Description of Flavobacterium columnare comb. nov. Flavobacterium columnare (basonym, Flexibacter columnaris (Davis 1922) Bernardet and Grimont 1989). The following combinations have been used for this species: Bacillus columnaris Davis 1922; Chondrococcus columnaris Ordal and Rucker 1944; Cytophaga columnaris Garnjobst 1945; Cytophaga columnaris Reichenbach 1989 (68); Flexibacter columnaris Leadbetter 1974 (49); and Flexibacter columnaris Bernardet and Grimont 1989 (10). The description of this taxon is the same as that given previously (10), except that tyrosine is not hydrolyzed. This species is frequently isolated from superficial lesions on 
TABLE 5-Continued

\begin{tabular}{|c|c|c|c|c|c|}
\hline Flavobacterium hydatis & $\begin{array}{l}\text { Flavobacterium } \\
\text { johnsoniae }\end{array}$ & $\begin{array}{l}\text { Flavobacterium } \\
\text { pectinovonum }\end{array}$ & $\begin{array}{l}\text { Flavobacterium } \\
\text { psychrophilum }\end{array}$ & $\begin{array}{l}\text { Flavobacterium } \\
\text { saccharophilum }\end{array}$ & $\begin{array}{l}\text { Flavobacterium } \\
\text { succinicans }\end{array}$ \\
\hline $\begin{array}{l}\text { Flat, spreading, with } \\
\text { filamentous margins }\end{array}$ & $\begin{array}{l}\text { Flat, spreading, with } \\
\text { filamentous margins }\end{array}$ & $\begin{array}{l}\text { Low convex, round, } \\
\text { with entire margins }\end{array}$ & $\begin{array}{l}\text { Low convex, round, } \\
\text { with entire or } \\
\text { uneven margins }\end{array}$ & $\begin{array}{l}\text { Flat, spreading, sunken } \\
\text { into agar }\end{array}$ & $\begin{array}{l}\text { Flat, spreading, with } \\
\text { filamentous margins }\end{array}$ \\
\hline - & $\mathrm{V}$ & - & - & - & - \\
\hline - & - & - & - & - & - \\
\hline+ & + & + & - & + & + \\
\hline+ & + & + & - & + & + \\
\hline+ & + & + & $(+)$ & + & + \\
\hline+ & + & + & + & + & - \\
\hline+ & + & + & - & + & + \\
\hline+ & + & + & - & ND & + \\
\hline+ & + & + & + & + & $(+)$ \\
\hline+ & + & + & + & + & + \\
\hline+ & + & + & - & + & + \\
\hline V & + & + & - & + & ND \\
\hline- & - & - & - & + & - \\
\hline - & + & + & - & ND & ND \\
\hline+ & + & + & - & + & ND \\
\hline$(+)$ & + & + & - & - & - \\
\hline+ & + & + & - & + & + \\
\hline+ & + & + & $(+)$ & - & + \\
\hline+ & + & + & $\mathrm{v}$ & + & - \\
\hline- & $\mathrm{v}$ & - & - & - & - \\
\hline- & - & - & + & - & - \\
\hline+ & + & + & - & + & + \\
\hline- & - & + & + & + & + \\
\hline - & - & $\mathrm{V}$ & - & + & - \\
\hline $\mathrm{V}$ & + & + & $\mathrm{V}$ & - & + \\
\hline+ & $\mathrm{v}$ & + & - & + & $\mathrm{v}$ \\
\hline
\end{tabular}

diseased fish and sometimes from internal organs. Pathogenicity for fish has been demonstrated by experimental infection tests (18).

Description of Flavobacterium flevense comb. nov. Flavobacterium flevense (basonym, Cytophaga flevensis van der Meulen, Harder, and Veldkamp 1974). The description of this taxon is the same as that given previously (90), with the following additions and modifications: starch, esculin, and Tween compounds are degraded; DNA, carboxymethyl cellulose, tyrosine, and lecithin are not degraded; catalase is produced; $o$-nitrophenyl- $\beta$-D-galactopyranoside is hydrolyzed; and good growth occurs on nutrient agar Trypticase soy agar (10).

Description of Flavobacterium hydatis nom. nov. Flavobacterium hydatis (basonym, Cytophaga aquatilis Strohl and Tait 1978) (hy' da.tis. Gr. n. hydor, water; N. L. gen. n. hydatis, from water). The description of this taxon is the same as that given previously for [Cytophaga] aquatilis (82), with the following additions and modifications: lecithin is not degraded; cytochrome oxidase is produced; $o$-nitrophenyl- $\beta$-D-galactopyranoside is hydrolyzed; and good growth occurs on Trypticase soy agar (10). The only currently available strain was isolated from the gills of a diseased salmon, but the pathogenicity of this organism has not been tested (82).

Description of Flavobacterium johnsoniae comb. nov. corrig. Flavobacterium johnsoniae (basonyms, Cytophaga johnsonae Stanier 1947, Cytophaga johnsonii Stanier 1957) (john.so' ni.ae. N. L. gen. fem. n. johnsoniae, of Johnson, named after D. E.
Johnson [see above]). The description of this taxon is the same as that given previously (68), with the following additions: good growth occurs on nutrient agar and Trypticase soy agar; tyrosine, esculin, tributyrin, and Tween compounds are degraded; lecithin is not degraded; and $o$-nitrophenyl- $\beta$-D-galactopyranoside is hydrolyzed $(10,61)$. Flavobacterium johnsoniae is common in soil and freshwater, and strains are frequently isolated from superficial lesions on diseased fish (9). Thus, for a long time this species was considered opportunistic, but some clues to its pathogenicity have been found recently (13). Flavobacterium johnsoniae includes two strains previously known as [Flexibacter] aurantiacus strains (strains NCIMB $1382^{\mathrm{T}}$ and NCIMB 1455) (see below).

Description of Flavobacterium pectinovorum comb. nov. Flavobacterium pectinovorum (basonym, Cytophaga pectinovora (Dorey 1959) Reichenbach 1989) was described as Flavobacterium pectinovonum by Dorey in 1959 (25), but this name was not included on the Approved Lists of Bacterial Names (75). It was later reclassified as Cytophaga johnsonae (15) and then restored as an independent species under the combination Cytophaga pectinovora (68). The description of this taxon is the same as that given previously (68), with the following additions: good growth occurs on nutrient agar and Trypticase soy agar; esculin and tyrosine are degraded, but no pigment is produced on tyrosine agar; no precipitate is formed on egg yolk agar; $o$-nitrophenyl- $\beta$-D-galactopyranoside is hydrolyzed; 
and the organism is susceptible to vibriostatic compound $\mathrm{O} / 129(8)$.

Description of Flavobacterium psychrophilum comb. nov. Flavobacterium psychrophilum (basonym, Flexibacter psychrophilus (Borg 1960) Bernardet and Grimont 1989) was described as Cytophaga psychrophila by Borg in 1960 (11); this combination was also used in Bergey's Manual of Systematic Bacteriology (68), but in a 1989 study Bernardet and Grimont proposed that this taxon should be transferred to the genus Flexibacter (10). The description of this taxon is the same as that given previously $(10,68)$. This species is frequently isolated from internal organs and superficial lesions of diseased fish, and pathogenicity for fish has been demonstrated by experimental infection tests (18).

Description of Flavobacterium saccharophilum comb. nov. Flavobacterium saccharophilum (basonym, Cytophaga saccharophila Agbo and Moss 1979). The description of this taxon is the same as that given previously $(1,68)$. Catalase and cytochrome oxidase activities were listed as positive in the original description of the species (1), but they were not observed in a later study (68). We clearly observed catalase activity, but no cytochrome oxidase activity was detected when we used both dimethylparaphenylene diamine (oxidase discs; bioMérieux, Marcy-l'Etoile, France) and tetramethylparaphenylene diamine (oxidase liquid reagent; bioMérieux). Good growth occurs on nutrient agar and Trypticase soy agar; esculin and tyrosine are degraded, but no pigment is produced on tyrosine agar; no precipitate is formed on egg yolk agar; and $o$-nitrophenyl- $\beta$-D-galactopyranoside is hydrolyzed (8).

Description of Flavobacterium succinicans comb. nov. Flavobacterium succinicans (basonym, Cytophaga succinicans Anderson and Ordal 1961). The combination Flexibacter succinicans has also been used for this species (49). The description of this taxon is the same as that given previously $(4,68)$. Good growth occurs on nutrient agar and Trypticase soy agar; esculin and DNA are degraded; tyrosine is not degraded; no precipitate is formed on egg yolk agar; $o$-nitrophenyl- $\beta$-D-galactopyranoside is hydrolyzed; the organism is susceptible to vibriostatic compound $\mathrm{O} / 129$; and $\mathrm{H}_{2} \mathrm{~S}$ is not produced (8). The three Flavobacterium succinicans strains currently available were isolated from superficial lesions on diseased fish and from water in a fish tank, but the pathogenicity of these strains was not tested (4).

Differentiation of Flavobacterium species. The main characteristics that differentiate the 10 valid species that belong to the emended genus Flavobacterium are shown in Table 5. Since the data in this table were collected from several references, it is possible that different procedures used in the different studies resulted in apparent phenotypic differences. Additional differentiating characteristics for the Flavobacterium species include their API ZYM profiles (Table 6) and their polyamine distribution patterns (see above).

We determined the fatty acid and protein profiles of all valid species and invalid taxa belonging to the Flavobacterium aquatile rRNA cluster (Table 4 and Fig. 2). Some differences in the fatty acid profiles of species are described above, and these differences are valuable characteristics for differentiating several species. From Fig. 2, it is obvious that whole-cell protein analysis combined with a computer-assisted numerical comparison of the patterns is a useful technique for differentiating Flavobacterium strains. As mentioned above, the different [Flexibacter] columnaris and [Flexibacter] psychrophilus strains which we studied are identical as determined by protein electrophoresis; this finding confirms that these two species are homogeneous genotypically, as determined by DNA-DNA hybridization (10). In this study, several species were represented by only one strain. However, other species exhibited various levels of protein electrophoretic heterogeneity (Fig. 2), as discussed below.

In the case of Flavobacterium succinicans, the protein profile of strain NCIMB 2279 is clearly different from the protein profiles of the two other strains, whereas the results of the fatty acid analysis can be used to differentiate strain NCIMB 2278 from the two other strains. These data confirm the previous observations that there are phenotypic differences in this species (68). The $\mathrm{G}+\mathrm{C}$ contents of the three strains are very similar (68) (Table 2), but no DNA-DNA hybridization study has been performed yet.

The seven Flavobacterium branchiophilum strains which we tested all produce very similar fatty acid profiles, but they can be separated into two very distinct groups when their protein profiles are compared. As there are no obvious differences in the phenotypic characteristics of these strains and they have very similar $\mathrm{G}+\mathrm{C}$ contents, additional studies (including DNA-DNA hybridization analyses) will be necessary to investigate the taxonomic structure of Flavobacterium branchiophilum.

The two strains belonging to the invalid taxon "[Sporocytophaga] cauliformis" clearly produce different fatty acid and protein profiles, which is consistent with the differences in $\mathrm{G}+\mathrm{C}$ contents and phenotypic characteristics noticed previously (68).

[Flexibacter] aurantiacus Lewin 1969 contains only two strains (50). Type strain NCIMB 1382 was previously considered a Cytophaga aurantiaca strain, while strain NCIMB 1455 was previously classified as a strain of [Cytophaga] psychrophila (synonym, [Flexibacter] psychrophilus [see above]). Both strains are phenotypically indistinguishable from the Flavobacterium johnsoniae type strain but very clearly different from both bona fide Cytophaga aurantiaca and [Flexibacter] psychrophilus strains $(9,10)$. In the 1990 National Collection of Industrial and Marine Bacteria Catalogue of Strains (57a) both strains are listed as "possibly [Cytophaga] johnsonae." Moreover, the two [Flexibacter] aurantiacus strains were the closest relatives of the Flavobacterium johnsoniae type strain when the fatty acid profiles were analyzed numerically by a principal-component analysis (data not shown). The data obtained from DNA-DNA hybridization studies (Table 3) confirmed that the two [Flexibacter] aurantiacus strains belong to the same species; their high levels of DNA-DNA relatedness and low $\Delta T_{m}$ with the DNA of the Flavobacterium johnsoniae type strain showed that these three strains form a tight genomic species. Thus, [Flexibacter] aurantiacus Lewin 1969 appears to be a junior synonym of [Cytophaga] johnsonae Stanier 1947, and we propose that it should be included in Flavobacterium johnsoniae. In general, Flavobacterium johnsoniae appears to be very heterogeneous. The type strain, two additional strains, and the former [Flexibacter] aurantiacus strains make up two separate electrophoretic subgroups. Similar intraspecific protein electrophoretic subgroups have been described for several other bacteria $(87,89)$. However, four additional strains, two of which (ATCC 29585 and ATCC 29586) form a single cluster, occupy distinct positions on the dendrogram (Fig. 2). DNA-DNA hybridization experiments performed with strains ATCC 29585 and ATCC 29586 revealed that these organisms exhibit a high level of DNA homology, which confirmed the general rule that the results of whole-cell protein electrophoresis can be used to group closely related strains. However, these strains and one of the other strains (LMG 11391) did not exhibit significant levels of DNA homology with other Flavobacterium johnsoniae strains. The fourth strain which occupied a separate position on the dendrogram was not included in the DNA-DNA hy- 
TABLE 6. API ZYM profiles of the type strains of the 10 valid species belonging to the genus Flavobacterium ${ }^{\prime \prime}$

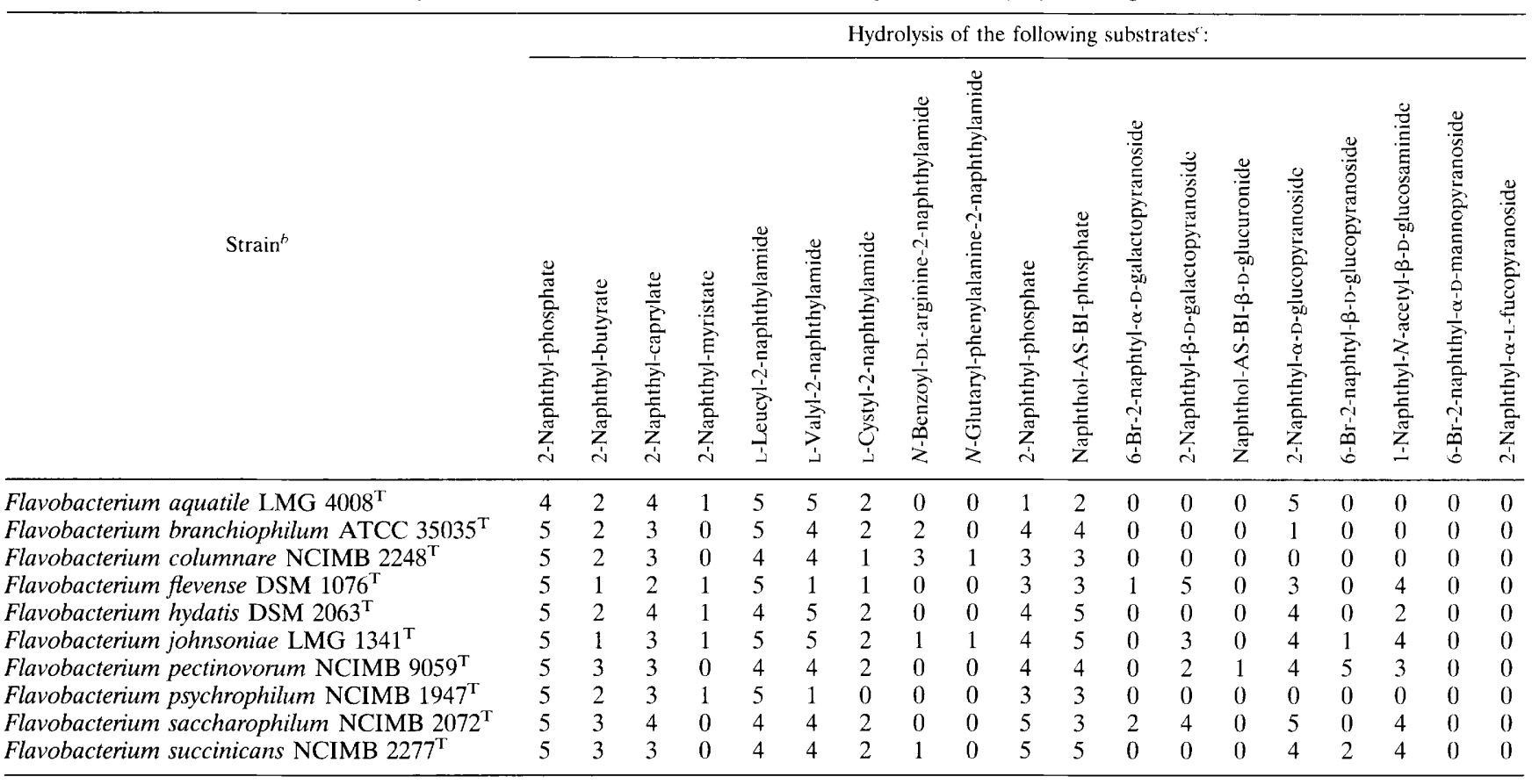

${ }^{a}$ Data from references 8 and 10 .

${ }^{b}$ See Table 1, footnote $a$.

c The values are API ZYM reaction scores.

bridization analysis. Our results confirm the previous conclusion concerning the phenotypic and genomic diversity of Flavobacterium johnsoniae (68). We concluded that clearly protein electrophoretic heterogeneity occurs in this species, but that most of the strains that produce aberrant protein patterns are misidentified field isolates.

Finally, the taxa "[Cytophaga $]$ allerginae," "[Cytophaga $]$ xantha," "[Flexibacter $]$ aurantiacus subsp. excathedrus," "[Promyxobacterium] flavum," and "[Sporocytophaga] cauliformis" clearly belong to the emended genus Flavobacterium, as shown by their phenotypic characteristics, rRNA homology data (Fig. 1 and Table 2), and fatty acid analysis data (Table 4). However, these names have not been validly published, and each of them except "[Sporocytophaga] cauliformis" is represented by only a single strain; two rather different strains of "[Sporocytophaga] cauliformis" are available (68). No 16S rRNA sequence data have been published for any of these organisms except one "[Sporocytophaga] cauliformis" strain (30). Thus, instead of creating five new Flavobacterium species, each represented by one or two poorly characterized strains, we decided to refer to these isolates as Flavobacterium sp., pending isolation of new strains. A larger collection of strains should enable researchers to properly describe these five taxa and to determine if each of them really represents a distinct species belonging to the genus Flavobacterium. Preliminary DNA-DNA hybridization studies have shown that the DNAs from "[Cytophaga] allerginae," "[Cytophaga] xantha," "[Promyxobacterium] flavum," and the two "[Sporocytophaga] cauliformis" strains do not exhibit significant levels of homology with DNAs from the Flavobacterium aquatile and Flavobacterium johnsoniae type strains (8).

Differentiation of Flavobacterium from related genera. The main characteristics that can be used to differentiate the emended genus Flavobacterium from several related taxa belonging to rRNA superfamily $\mathrm{V}$ are shown in Table 7. The following taxa were included in Table 7: (i) the closest phylogenetic relative of the Flavobacterium rRNA branch, as determined by DNA-rRNA hybridization (i.e., [Flavobacterium] odoratum) (Fig. 1); (ii) the genera to which the valid species included in the emended genus Flavobacterium were previously assigned (i.e., the genera Cytophaga and Flexibacter; these genera are represented by their type species, Cytophaga hutchinsonii and Flexibacter flexilis, respectively); (iii) the genera that now contain species that previously were considered Flavobacterium species (i.e., the genera Bergeyella, Chryseobacterium, Empedobacter, Sphingobacterium, and Weeksella; the genera Bergeyella, Empedobacter, and Weeksella are represented by their type and only species, Bergeyella zoohelcum, Empedobacter brevis, and Weeksella virosa, respectively); and (iv) other taxa belonging to the emended family Flavobacteriaceae (see below).

Delineation of the families belonging to the Cytophaga-Flavobacterium-Bacteroides rRNA homology group. In Bergey's Manual of Systematic Bacteriology, the genera Flavobacterium, Cytophaga, and Flexibacter were placed in the order Cytophagales along with several other related taxa (68). This definition of the order took into account classical phenotypic characteristics, recent data obtained from chemotaxonomic investigations, and the first results of rRNA studies. The following two families were included in the order Cytophagales: the family Cytophagaceae Stanier 1940 (including the genera Cytophaga, Capnocytophaga, Flexithrix, and Sporocytophaga; the genera Flexibacter, Microscilla, and Chitinophaga were considered close relatives of this family) and the proposed family "Flavobacteriaceae." The name of the latter family, which contained strictly aerobic, nonmotile, nongliding, free-living or parasitic organisms, was subsequently validated (44a). The following other taxa were considered rather close relatives of the order Cytophagales: the family Bacteroidaceae Pribram 1933 
TABLE 7. Characteristics that can be used to differentiate the emended genus Flavobacterium, related taxa belonging to rRNA superfamily $\mathrm{V}$, and the taxa included in the emended family Flavobacteriaceae ${ }^{a}$

\begin{tabular}{|c|c|c|c|c|c|c|}
\hline Characteristic & Flavobacterium & $\begin{array}{c}\text { [Flavobacterium }] \\
\text { odoratum }\end{array}$ & $\begin{array}{l}\text { Cytophaga } \\
\text { hutchinsonii }\end{array}$ & $\begin{array}{l}\text { Flexibacter } \\
\text { flexilis }\end{array}$ & Sphingobacterium & Chryseobacterium \\
\hline Habitat & $\begin{array}{r}\text { Free living or } \\
\text { saprophytic }\end{array}$ & $\begin{array}{r}\text { Free living or } \\
\text { saprophytic }\end{array}$ & $\begin{array}{l}\text { Free living } \\
\text { (soil) }\end{array}$ & $\begin{array}{l}\text { Free living } \\
\quad \text { (freshwater) }\end{array}$ & $\begin{array}{l}\text { Free living or } \\
\text { saprophytic }\end{array}$ & $\begin{array}{l}\text { Free living or } \\
\text { parasitic }\end{array}$ \\
\hline Pigmented colonies & $+b$ & + & + & + & $(+)$ & + \\
\hline Gliding motility & $+^{c}$ & - & + & + & - & - \\
\hline Menaquinone $e^{e}$ & MK-6 & MK-6 & MK-7 & ND & MK-7 & MK-6 \\
\hline Capnophilic metabolism & - & - & - & - & - & - \\
\hline Presence of sphingophospholipids & - & - & ND & ND & + & - \\
\hline Growth at $37^{\circ} \mathrm{C}$ & - & + & - & - & $\mathrm{v}$ & $+^{f}$ \\
\hline Growth at $42^{\circ} \mathrm{C}$ & - & - & - & - & $-g$ & $\mathrm{v}$ \\
\hline Growth on MacConkey agar & ND & + & ND & ND & + & $t^{h}$ \\
\hline Growth on $\beta$-hydroxybutyrate & ND & + & ND & ND & ND & + \\
\hline Acid production from glucose & $\mathrm{v}$ & - & + & + & + & $+^{i}$ \\
\hline Acid production from sucrose & $\mathrm{v}$ & - & ND & ND & + & - \\
\hline DNase activity & $\mathrm{v}$ & + & - & ND & $\mathrm{v}$ & + \\
\hline Urease activity & $\mathrm{v}$ & + & + & ND & $\mathrm{V}$ & $\mathrm{v}$ \\
\hline Catalase activity & + & + & + & - & + & + \\
\hline Production of indole & - & - & - & - & - & $v^{i}$ \\
\hline Degradation of cellulose & - & - & + & - & - & - \\
\hline Degradation of esculin & $\mathrm{v}$ & - & ND & ND & + & + \\
\hline Degradation of gelatin & $+^{c}$ & + & + & + & $\mathrm{v}$ & + \\
\hline Resistance to penicillin $G$ & $\mathrm{v}$ & ND & ND & ND & ND & + \\
\hline $\mathrm{G}+\mathrm{C}$ content $(\mathrm{mol} \%)$ & $32-37$ & 37 & 40 & $40-43$ & $39-45$ & $33-38$ \\
\hline
\end{tabular}

a Data from references $9,10,19,20,24,37,41-44,45,46,61,68,72,84,85,88$, and 102 and this study. Additional phenotypic characteristics that differentiate the Capnocytophaga species, Ornithobacterium rhinotracheale, and Riemerella anatipestifer are described in reference 88. only.

+ , positive reaction; - , negative reaction; $(+)$, weak positive reaction; $v$, variable within and between species; ND, not determined or determined for some species

'See exceptions in Table 5 .

${ }^{d}$ Positive for all members of the rRNA cluster except [Flavobacterium] gondwanense and [Flavobacterium] salegens.

'MK-6, menaquinone 6; MK-7, menaquinone 7.

Most strains are positive for this characteristic.

${ }^{g}$ Negative for all Sphingobacterium species except Sphingobacterium thalpophilum.

"Strain dependent for Chryseobacterium indologenes. Positive for all other Chryseobacterium species except Chryseobacterium scophthalmum.

iStrain dependent for Chryseobacterium meningosepticum. Positive for all other Chryseobacterium species except Chryseobacterium scophthalmum.

' Positive for all Capnocytophaga species except Capnocytophaga canimorsus.

(36) and the ring-forming bacteria, which were later placed in a fourth family, the Spirosomaceae Larkin and Borrall 1978 (48). The general structure of the order Cytophagales and related taxa was later confirmed and completed by new data obtained from rRNA studies $(30,56,58,72,101)$. Thus, this taxonomic entity seems to correspond to the phylogenetic entity called superfamily V or the "flavobacter-bacteroides" phylum depending on the authors and the method used for rRNA homology studies $(30,73)$.

Because of the taxonomic and nomenclatural changes proposed in this study and in other recent publications (85), there are many new problems concerning the definition of the families Flavobacteriaceae and Cytophagaceae (38). An emended genus Cytophaga (i.e., a genus restricted to Cytophaga hutchinsonii and a few other cellulolytic taxa) must remain the type genus of the family Cytophagaceae. Most other misclassified Cytophaga and Flexibacter species have already been placed in other genera or new genera. The emended genus Flavobacterium proposed in this paper is the type genus of the family Flavobacteriaceae, but the current description of this genus is indeed much more similar to the description of "noncellulolytic cytophagas" than to its previous description.

The levels of genotypic divergence corresponding to differences in $T_{m(e)}$ of $14^{\circ} \mathrm{C}$ or more (Fig. 1 and Table 2) between former members of the genus Flavobacterium are far too great to include all of these bacteria in a single family. On the other hand, from a phenotypic and chemotaxonomic point of view, it would not be logical to separate some of the taxa belonging to different major rRNA clusters or solitary rRNA branches, such as the genera Chryseobacterium and Empedobacter or the genera Ornithobacterium and Riemerella. Three of the rRNA clusters (the Chryseobacterium-Bergeyella-Riemerella rRNA cluster, the Empedobacter-Weeksella rRNA cluster, and the Flavobacterium aquatile rRNA cluster) and two solitary rRNA branches (the Ornithobacterium and Capnocytophaga rRNA branches) are linked at an average $T_{m(e)}$ of about $65^{\circ} \mathrm{C}$, which corresponds to a difference in $T_{m(e)}$ of about $14^{\circ} \mathrm{C}$. The differences in $T_{m(e)}$ within most well-characterized families of bacteria are in the range from 8 to $12^{\circ} \mathrm{C}$. In our opinion, the phenotypic similarities of all of the taxa that clustered above a value of $65^{\circ} \mathrm{C}$ in this study overcame the obviously high levels of genotypic divergence. A major problem in the chemotaxonomic description of this group was the previously reported presence of menaquinone 7 as the sole respiratory quinone in Ornithobacterium and Riemerella strains (27), while menaquinone 6 is the only quinone found in members of the genera Capnocytophaga, Chryseobacterium, Empedobacter, and Flavobacterium (as defined in this study), [Flavobacterium] odoratum, members of the [Flexibacter] maritimus rRNA branch, and Weeksella virosa $(56,85)$ (no data for Bergeyella zoohelcum are available). However, the menaquinone contents of two reference strains of Ornithobacterium rhinotracheale and two reference strains of Riemerella anatipestifer were determined by high-performance liquid chromatography and mass spectrometry, and all four strains were found to contain large amounts of menaquinone 6 and trace amounts of menaquinone 5 (47). Thus, the taxa 
TABLE 7-Continued

\begin{tabular}{|c|c|c|c|c|c|c|}
\hline $\begin{array}{l}\text { Empedobacter } \\
\text { brevis }\end{array}$ & Weeksella virosa & $\begin{array}{l}\text { Bergeyella } \\
\text { zoohelcum }\end{array}$ & Capnocytophaga & $\begin{array}{l}\text { Ornithobacterium } \\
\text { rhinotracheale }\end{array}$ & $\begin{array}{l}\text { Riemerella } \\
\text { anatipestifer }\end{array}$ & $\begin{array}{l}\text { [Flexibacter] maritimus } \\
\text { rRNA cluster }\end{array}$ \\
\hline $\begin{array}{l}\text { Free living or } \\
\text { parasitic }\end{array}$ & $\begin{array}{l}\text { Parasitic or } \\
\text { saprophytic }\end{array}$ & $\begin{array}{l}\text { Parasitic or } \\
\text { saprophytic }\end{array}$ & $\begin{array}{l}\text { Parasitic or } \\
\text { saprophytic }\end{array}$ & Parasitic & Parasitic & $\begin{array}{l}\text { Free living (marine environ- } \\
\text { ment) or saprophytic }\end{array}$ \\
\hline+ & - & - & + & - & - & +1 \\
\hline _- & _- & - & + & - & - & $+d$ \\
\hline MK-6 & MK-6 & ND & MK-6 & MK-6 & MK-6 & MK-6 \\
\hline- & -- & - & + & + & + & - \\
\hline- & - & - & ND & ND & ND & ND \\
\hline$+f$ & + & + & + & + & + & - \\
\hline - & + & - & ND & + & $+t$ & - \\
\hline+ & + & - & - & - & - & ND \\
\hline+ & + & - & ND & ND & ND & ND \\
\hline$+f$ & -- & - & + & $\mathrm{v}$ & $\mathrm{v}$ & $\mathrm{v}$ \\
\hline - & -. & - & $+{ }^{i}$ & - & - & $\mathrm{v}$ \\
\hline+ & - & - & ND & - & ND & ND \\
\hline- & - & + & ND & + & $\mathrm{v}$ & $\mathrm{v}$ \\
\hline+ & + & + & $\mathrm{v}$ & - & + & $\mathrm{v}$ \\
\hline+ & + & + & - & - & - & - \\
\hline - & - & - & - & - & - & - \\
\hline- & - & - & + & - & ND & ND \\
\hline+ & + & + & $v$ & - & $+r$ & $\mathrm{v}$ \\
\hline+ & - & - & - & $\mathrm{v}$ & - & ND \\
\hline $31-33$ & $35-38$ & $35-37$ & $34-40$ & $37-39$ & $29-35$ & $33-42$ \\
\hline
\end{tabular}

belonging to each cluster and branch in this bacterial group contain the same respiratory quinone. The members of three genera (the genera Capnocytophaga, Ornithobacterium, and Riemerella) exhibit similar capnophilic metabolism (88), while the other taxa are considered obligately aerobic (68). In fact, within a genus whose members are for the most part aerobic, such as the emended genus Flavobacterium proposed above, some species may exhibit capnophilic behavior under certain conditions (this is true of Flavobacterium hydatis and Flavobacterium succinicans). Moreover, other well-defined bacterial families contain organisms that have rather different types of metabolism (86). Thus, we believe that the phenotypic similarities, as well as the genotypic similarities, of all of these organisms justify their inclusion in a single family. The emended description of the family Flavobacteriaceae below is a compilation of previously published phenotypic data $(43,44,72,85$, 88) (Table 5).

Emended description of the family Flavobacteriaceae Reichenbach 1989. Cells are short to moderately long rods with parallel or slightly irregular sides and rounded or slightly tapered ends and are usually 0.3 to $0.6 \mu \mathrm{m}$ wide and 1 to $10 \mu \mathrm{m}$ long, but some species may form filamentous flexible cells under certain growth conditions. Cells in old cultures may form spherical or coccoid bodies. Gram negative. Spores are not formed. Flagella are absent. Nonmotile (Bergeyella, Chryseobacterium, Empedobacter, [Flavobacterium] odoratum, Ornithobacterium, Riemerella, and Weeksella strains) or motile by gliding (Capnocytophaga and Flavobacterium strains and members of the [Flexibacter] maritimus rRNA branch). Growth is aerobic (Bergeyella, Chryseobacterium, Empedobacter, Flavobacterium, [Flavobacterium $]$ odoratum, and Weeksella strains and members of the [Flexibacter] maritimus rRNA branch) or microaerobic to anaerobic (Capnocytophaga, Ornithobacterium, and Riemerella strains). The optimum temperature is usually in the range from 25 to $35^{\circ} \mathrm{C}$. Colonies are nonpigmented (Bergeyella, Ornithobacterium, Riemerella, and Weeksella strains) or pigmented by carotenoid or flexirubin types of pigments or both (Capnocytophaga, Chryseobacterium, Empedo- bacter, Flavobacterium, and [Flavobacterium] odoratum strains and members of the [Flexibacter] maritimus rRNA branch). Menaquinone 6 is the only respiratory quinone or the major respiratory quinone. Chemoorganotrophic. Intracellular granules of poly- $\beta$-hydroxybutyrate are absent. Sphingophospholipids are absent. Homospermidine is the major polyamine, and agmatine and putrescine are frequently present as minor components. Cellulose is not decomposed. The DNA base composition ranges from 29 to $45 \mathrm{~mol} \%$. Mostly saprophytic in terrestrial and aquatic habitats. Several members of the family are commonly isolated from diseased humans or animals; some species are considered true pathogens.

The type genus is Flavobacterium Bergey, Harrison, Breed, Hammer, and Huntoon 1923, as emended in this study. Other taxa included in the family are the genera Bergeyella, Capnocytophaga, Chryseobacterium, Empedobacter, Ornithobacterium, Riemerella, and Weeksella, [Flavobacterium] odoratum, and the taxa belonging to the [Flexibacter] maritimus rRNA branch. Differential characteristics for the taxa belonging to the family Flavobacteriaceae are shown in Table 7.

\section{ACKNOWLEDGMENTS}

We thank Brigitte Kerouault, Richard Tytgat, and Urbain Torck for excellent technical assistance. We are very grateful to T. O. MacAdoo (Department of Foreign Languages, Virginia Polytechnic Institute and State University, Blacksburg) for his expert advice concerning bacterial nomenclature and to B. Holmes (National Collection of Type Cultures, London, United Kingdom) for kindly reviewing the manuscript. We thank all of the individuals who provided strains (Table 1) and our colleagues on the International Committee on Systematic Bacteriology Subcommittee on the Taxonomy of Flavobacterium and CytophagaLike Bacteria who kindly supported our work by providing free bacterial strains and advice. We are very grateful to Eiko Yabuuchi (Osaka City University Medical School, Osaka, Japan) for kindly offering to verify the menaquinone contents of Ornithobacterium rhinotracheale and Riemerella anatipestifer and to Yoshimasa Kosako (The Institute of Physical and Chemical Research, Japan Collection of Microorganisms, Saitama, Japan) for kindly performing the menaquinone analysis. 
J.-F.B. thanks the North American Treaty Organization for a research grant. P.V. is indebted to the National Fund for Scientific Research (Belgium) for a position as a postdoctoral research fellow. K.K. is indebted to the Fund for Medical Scientific Research (Belgium) for research and personnel grants. Part of this research was performed in the framework of CEC contract BIOT-CT91-0294.

\section{REFERENCES}

1. Agbo, J. A. C., and M. O. Moss. 1979. The isolation and characterization of agarolytic bacteria from a lowland river. J. Gen Microbiol. 115.355-368.

2. Aiba, H., S. Adhya, and B. de Crombrugghe. 1981. Evidence for two functional gal promoters in intact Escherichia coli cells. J. Biol. Chem. 256: 11905-11910.

3. Anacker, R. L., and E. J. Ordal. 1955. Study of a bacteriophage infecting the myxobacterium Chondrococcus columnaris. J. Bacteriol. 70:738-741.

4. Anderson, R. L., and E. J. Ordal. 1961. Cytophaga succinicans sp. n., a facultatively anaerobic, aquatic myxobacterium. J. Bacteriol. 81:130-138.

5. Andresson, O. S., and O. H. Fridjonsson. 1994. The sequence of the single $16 \mathrm{~S}$ rRNA gene of the thermophilic eubacterium Rhodothermus marinus reveals a distant relationship to the group containing Flexibacter, Bacteroides, and Cytophaga species. J. Bacteriol. 176:6165-6169.

6. Bauwens, M. and J. De Ley, 1981. Improvements in the taxonomy of Flavobacterium by DNA:rRNA hybridizations, p. 27-31. In $\mathrm{H}$. Reichenbach and O. Weeks (ed.), The Flavobacterium-Cytophaga group. GBF Monograph series no. 5. Verlag Chemie, Weinheim, Germany.

7. Bergey, D. H., F. C. Harrisson, R. S. Breed, B. W. Hammer, and F. M. Huntoon. 1923. Bergey's manual of determinative bacteriology, 1st ed. The Williams and Wilkins Co., Baltimore.

8. Bernardet, J.-F. Unpublished data.

9. Bernardet, J.-F. 1989. Etude phénotypique et génomique des bactéries appartenant aux genres Cytophaga et Flexibacter (ordre des Cytophagales) et comparaison avec le genre Flavobacterium; application à l'identification et à la taxonomie des espèces ichtyopathogènes. Ph.D. thesis. Universite Paris 7, Paris, France.

10. Bernardet, J.-F, and P. A. D. Grimont. 1989. Deoxyribonucleic acid relatedness and phenotypic characterization of Flexibacter columnaris sp. nov. nom. rev., Flexibacter psychrophilus sp. nov., nom. rev., and Flexibacter maritimus Wakabayashi, Hikida, and Masumura 1986. Int. J. Syst. Bacteriol. 39:346-354.

11. Borg, A. F. 1960. Studies on myxobacteria associated with diseases in salmonid fishes. In Wildlife disease 8. American Association for the Advancement of Science, Washington, D.C.

12. Brenner, D. J., A. C. McWhorter, J. K. Leete Knutson, and A. G. Steigerwalt. 1982. Escherichia vulneris: a new species of Enterobacteriaceae associated with human wounds. J. Clin. Microbiol. 15:1133-1140.

13. Carson, J., L. M. Schmidtke, and B. L. Munday. 1993. Cytophaga johnsonae: a putative skin pathogen of juvenile farmed barramundi, Lates calcarifer Bloch. J. Fish Dis. 16:209-218.

14. Chase, J. M. 1965. Nutrition of some aquatic myxobacteria. M. S. thesis University of Washington, Seattle.

15. Christensen, P. J. 1977. The history, biology and taxonomy of the Cytophaga group. Can. J. Microbiol. 23:1599-1653.

16. Christensen, P. J. 1980. Description and taxonomic status of Cytophaga heparina (Payza and Korn) comb. nov. (basionym: Flavobacterium hepar num Payza and Korn 1956). Int. J. Syst. Bacteriol. 30:473-475.

17. Crosa, J. H., D. J. Brenner, and S. Falkow. 1973. Use of single-strandspecific nuclease for analysis of bacterial and plasmid deoxyribonucleic acid homo- and heteroduplexes. J. Bacteriol. 115:904-911.

18. Dalsgaard, I. 1993. Virulence mechanisms in Cytophaga psychrophila and other Cytophaga-like bacteria pathogenic for fish, p. 127-144. In M. Faisal and F. M. Hetrick (ed.), Annual review of fish diseases. Pergamon Press, New York.

19. Dees, S. B., G. M. Carlone, D. Hollis, and C. W. Moss. 1985. Chemical and phenotypic characteristics of Flavobacterium thalpophilum compared with those of other Flavobacterium and Sphingobacterium species. Int. J. Syst. Bacteriol, 35:16-22.

20. Dees, S. B., C. W. Moss, D. G. Hollis, and R. E. Weaver. 1986. Chemical characterization of Flovobacterium odoratum, Flavobacterium breve, and Flavobacterium-like groups IIe, IIh, and IIf. J. Clin. Microbiol. 23:267-273.

21. De Ley, J. 1970. Reexamination of the association between melting point buoyant density, and chemical base composition of deoxyribonucleic acid. $\mathbf{J}$. Bacteriol. 101:738-754.

22. De Ley, J. 1992. The Proteobacteria: ribosomal RNA cistron similarities and bacterial taxonomy, p. 2111-2140. In A. Balows, H. G. Trüper, M. Dworkin, W. Harder, and K.-H. Schleifer (ed.), The prokaryotes, 2nd ed., vol. 2. Springer-Verlag, Berlin.

23. De Ley, J., and J. De Smedt. 1975. Improvements of the membrane filter method for DNA:rRNA hybridization. Antonie Leeuwenhoek 41:287-307.

24. Dobson, S. J., R. R. Colwell, T. A. McMeekin, and P. D. Franzmann. 1993 Direct sequencing of the polymerase chain reaction-amplified 16S rRNA gene of Flavobacterium gondwanense sp. nov, and Flavobacterium salegens sp. nov., two new species from a hypersaline antarctic lake. Int. J. Syst. Bacteriol. 43:77-83.

25. Dorey, M. J. 1959. Some properties of a pectinolytic soil flavobacterium. J. Gen. Microbiol. 20:91-104.

26. Drijber, R. A., and W. B. McGill. 1994. Sulfonolipid content of Cytophaga and Flexibacter species isolated from soil and cultured under different nutrient and temperature regimes. Can. J. Microbiol. 40:132-139.

27. Engelhard, E. 1992. Unterzuchungen zur Chemotaxonomie der Familie Pasteurellaceae anhand von Kapillargaschromatographie zellulärer Kolenhydrate, Hochdruckflüssigkeitschromatographie und Dünnschichtchromatographie zellulärer Lipoide, verschiedener Hydrolasen und InfrarotMassenspektroskopie. Ph.D. thesis. Philipps-Universität Marburg, Marburg, Germany.

28. Fautz, E., and H. Reichenbach. 1980. A simple test for flexirubin-type pigments. FEMS Microbiol. Lett. 8:87-91.

29. Follett, E. A. C., and D. M. Webley. 1965. An electron microscope study of the cell surface of Cytophaga johnsonii and some observations on related organisms. Antonie van Leeuwenhoek J. Microbiol. Serol. 31:361-382.

30. Gherna, R., and C. R. Woese. 1992. A partial phylogenetic analysis of the "Flavobacter-Bacteroides" phylum: basis for taxonomic restructuring. Syst. Appl. Microbiol. 15:513-521.

31. Grimont, P. A. D., M. Y. Popoff, F. Grimont, C. Coynault, and M. Lemelin. 1980. Reproducibility and correlation study of three deoxyribonucleic acid hybridization procedures. Curr. Microbiol. 4:325-330.

32. Haack, S. K., and J. A. Breznak. 1993. Cytophaga xylanolytica sp. nov,, a xylan-degrading, anaerobic gliding bacterium. Arch. Microbiol. 159:6-15.

33. Hamana, K., and S. Matsuzaki. 1990. Occurrence of homospermidine as a major polyamine in the authentic genus Flavobacterium. Can. J. Microbiol. 36:228-231.

34. Hamana, K., Y. Nakagawa, and K. Yamasato. 1995. Chemotaxonomic significance of polyamine distribution patterns in the Flavobacterium-Cytophaga complex and related genera. Microbios 81:135-145.

35. Hansen, G. H., Ø. Bergh, J. Michaeisen, and D. Knappskog. 1992. Flexibacter ovolyticus sp. nov., a pathogen of eggs and larvae of atlantic halibut. Hippoglossus hippoglossus L. Int. J. Syst. Bacteriol. 42:451-458.

36. Holdeman, L. V., R. W. Kelley, and W. E. C. Moore. 1984. Family I Bacteroidaceae Pribram 1933, $10^{\mathrm{AL}}$, p. 602-662. In N. R. Krieg and J. G. Holt (ed.), Bergey's manual of systematic bacteriology, vol. 1. The Williams and Wilkins Co., Baltimore.

37. Holmes, B. 1992. The genera Flavobacterium, Sphingobacterium and Weeksella, p. 3620-3630. In A. Balows, H. G. Trüper, M. Dworkin, W. Harder, and K.-H. Schleifer (ed.), The prokaryotes, 2nd ed., vol. 4. Springer-Verlag, Berlin.

38. Holmes, B. 1993. Recent developments in Flavobacterium taxonomy, p. 6-15. In P. J. Jooste (ed.), Advances in the taxonomy and significance of Flavobacterium, Cytophaga and related bacteria. University of the Orange Free State Press, Bloemfontein, South Africa.

39. Holmes, B., and R. J. Owen. 1979. Proposal that Flavobacterium breve be substituted as the type species of the genus in place of Flavobacterium aquatile and emended description of the genus Flavobacterium: status of the named species of Flavobacterium. Request for an opinion. Int. J. Syst. Bacteriol. 29:416-426.

40. Holmes, B., R. J. Owen, and T. A. McMeekin. 1984. Genus Flavobacterium Bergey, Harrison, Breed, Hammer and Huntoon 1923, 97 AL p. 353-361. In N. R. Krieg and J. G. Holt (ed.), Bergey's manual of systematic bacteriology, vol. 1. The Williams and Wilkins Co., Baltimore.

41. Holmes, B., J. J. S. Snell, and S. P. Lapage. 1977. Revised description, from clinical isolates, of Flavobacterium odoratum Stutzer and Kwaschnina 1929, and designation of the neotype strain. Int. J. Syst. Bacteriol. 27:330-336.

42. Holmes, B., J. J. S. Snell, and S. P. Lapage. 1978. Revised description, from clinical strains, of Flavobacterium breve (Lustig) Bergey et al. 1923 and proposal of the neotype strain. Int. J. Syst. Bacteriol. 28:201-208.

43. Holmes, B., A. G. Steigerwalt, R. E. Weaver, and D. J. Brenner. 1986 Weeksella virosa gen. nov., sp. nov. (formerly group IIf), found in human clinical specimens. Syst. Appl. Microbiol. 8:185-190.

44. Holmes, B., A. G. Steigerwalt, R. E. Weaver, and D. J. Brenner. 1986 Weeksella zoohelcum sp. nov. (formerly group $\mathrm{IIj}$ ), from human clinical specimens. Syst. Appl. Microbiol. 8:191-196.

44a.International Journal of Systematic Bacteriology. 1992. Validation of the publication of new names and new combinations previously effectively published outside the IJSB. List no. 41. Int. J. Syst. Bacteriol. 42:327-329.

45. Kath, T., and H. Reichenbach. 1993. A study into the taxonomy of cellulosedegrading Cytophaga and Sporocytophaga, p. 171-181. In P. J. Jooste (ed.) Advances in the taxonomy and significance of Flavobacterium, Cytophage and related bacteria. University of the Orange Free State Press, Bloemfontein, South Africa.

46. Kath, T. K. L. 1990. Untersuchungen zur natürlichen Verwandtschaft cellulosezersetzender Cytophaga-artiger Bakterien. Ph.D. thesis. Technical University of Braunschweig, Braunschweig, Germany.

47. Kosako, Y. Personal communication.

47a.Lapage, S. P., P. H. A. Sneath, E. F. Lessel, V. B. D. Skerman, H. P. R. Seeliger, and W. A. Clark (ed.). 1975. International code of nomenclature 
of bacteria. 1976 revision. American Society for Microbiology, Washington, D.C.

48. Larkin, J. M., and R. Borrall. 1984. Family I. Spirosomaceae Larkin and Borrall 1978, 595 AL , p. 125-132. In N. R. Krieg and J. G. Holt (ed.), Bergey's manual of systematic bacteriology, vol. 1. The Williams and Wilkins Co., Baltimore.

49. Leadbetter, E. R. 1974. Order II. Cytophagales nomen novum, p. 99-122. In R. E. Buchanan and N. E. Gibbons (ed.), Bergey's manual of determinative bacteriology, 8th ed. The Williams and Wilkins Co., Baltimore.

50. Lewin, R. A. 1969. A classification of flexibacteria. J. Gen. Microbiol. 58: $189-206$

51. Marmur, J., and P. Doty. 1962. Determination of the base composition of deoxyribonucleic acid from its thermal denaturation temperature. J. Mol. Biol. 5:109-118.

52. McCurdy, H. D., Jr. 1969. Studies on the taxonomy of the Myxobacterales. I. Record of Canadian isolates and survey of methods. Can. J. Microbiol. 15:1453-1461.

53. McGuire, A. J., P. D. Franzmann, and T. A. McMeekin. 1987. Flectobacillus glomeratus sp. nov., a curved, nonmotile, pigmented bacterium isolated from antarctic marine environments. Syst. Appl. Microbiol. 9:265-272

54. Mudarris, M., B. Austin, P. Segers, M. Vancanneyt, B. Hoste, and J.-F. Bernardet. 1994. Flavobacterium scophthalmum sp. nov., a pathogen of turbot (Scophthalmus maximus L.). Int. J. Syst. Bacteriol. 44:447-453.

55. Naganuma, T., and K. Horikoshi. 1994. Cellular fatty acids of marine agarolytic gliding bacteria. Syst. Appl. Microbiol. 17:125-127.

56. Nakagawa, Y., and K. Yamasato. 1993. Phylogenetic diversity of the genus Cytophaga revealed by $16 \mathrm{~S}$ rRNA sequencing and menaquinone analysis. J. Gen. Microbiol. 139:1155-1161.

57. Nakagawa, Y., and K. Yamasato. 1994. Phylogenetic analysis of the Flavobacterium-Cytophaga complex, p. 228. In Abstract Book of the 7th International Congress of Bacteriology and Applied Microbiology. Czechoslovak Society for Microbiology, Prague, Czech Republic.

57a.National Collection of Industrial and Marine Bacteria. 1990. Catalogue of strains. National Collection of Industrial and Marine Bacteria, Aberdeen, Scotland.

58. Neefs, J. M., Y. Van De Peer, P. De Rijk, S. Chapelle, and R. De Wachter. 1993. Compilation of small ribosomal subunit RNA structures. Nucleic Acids Res. 21:3025-3049.

59. Olsen, G. J., C. R. Woese, and R. Overbeek. 1994. The winds of (evolutionary) change: breathing new life into microbiology. J. Bacteriol. 176:1-6.

60. Owen, R. J., and B. Holmes. 1978. Heterogeneity in the characteristics of deoxyribonucleic acid from Flavobacterium odoratum. FEMS Microbiol. Lett. 48:41-46.

61. Oyaizu, H., and K. Komagata. 1981. Chemotaxonomic and phenotypic characterization of the strains of species in the Flavobacterium-Cytophaga complex. J. Gen. Appl. Microbiol. 27:57-107.

62. Paster, B. J., F. E. Dewhirst, I. Olsen, and G. J. Fraser. 1994. Phylogeny of Bacteroides, Prevotella, and Porphyromonas spp. and related bacteria. J. Bacteriol. 176:725-732.

63. Paster, B. J., W. Ludwig, W. G. Weisburg, E. Stackebrandt, R. B. Hespell, C. M. Hahn, H. Reichenbach, K. O. Stetter, and C. R. Woese. 1985. A phylogenetic grouping of the bacteroides, cytophagas, and certain flavobacteria. Syst. Appl. Microbiol. 6:34-42.

64. Patel, B. K. C., D. S. Saul, R. A. Reeves, L. C. Williams, J. E. Cavanagh, P. D. Nichols, and P. L. Bergquist. 1994. Phylogeny and lipid composition of Thermonema lapsum, a thermophilic gliding bacterium. FEMS Microbiol. Lett. 115:313-317.

65. Popoff, M. Y., C. Coynault, M. Kiredjian, and M. Lemelin. 1981, Polynucleotide sequence relatedness among motile Aeromonas species. Curr. Microbiol. 5:109-114.

66. Pringsheim, E. G. 1951 . The Vitreoscillaceae: a family of colourless, gliding, filamentous organisms. J. Gen. Microbiol. 5:124-149.

67. Raj, H. D., and S. R. Maloy. 1990. Proposal of Cyclobacterium marinus gen. nov., comb. nov., for a marine bacterium previously assigned to the genus Flectobacillus. Int. J. Syst. Bacteriol. 40:337-347.

68. Reichenbach, H. 1989. Order I. Cytophagales Leadbetter 1974, 99AI, p. 2011-2013. In J. T. Staley, M. P. Bryant, N. Pfennig, and J. G. Holt (ed.), Bergey's manual of systematic bacteriology, vol. 3. The Williams and Wilkins Co., Baltimore.

69. Reichenbach, H. 1992. The order Cytophagales, p. 3631-3687. In A. Balows, H. G. Trüper, M. Dworkin, W. Harder, and K.-H. Schleifer (ed.), The prokaryotes, 2nd ed., vol. 4. Springer-Verlag, Berlin.

70. Reichenbach, H. 1993. Recent developments in the taxonomy of the cytophagas, p. 152-162. In P. J. Jooste (ed.), Advances in the taxonomy and significance of Flavobacterium, Cytophaga and related bacteria. University of the Orange Free State Press, Bloemfontein, South Africa.

71. Reichenbach, H. 1993. Taxeobacter, a new genus of the Cytophagales with three new species, p. 182-185. In P. J. Jooste (ed.), Advances in the taxonomy and significance of Flavobacterium, Cytophaga and related bacteria. University of the Orange Free State Press, Bloemfontein, South Africa.

72. Segers, P., W. Mannheim, M. Vancanneyt, K. De Brandt, K.-H. Hinz, K. Kersters, and P. Vandamme. 1993. Riemerella anatipestifer gen. nov., the causative agent of septicemia anserum exsudativa, and its phylogenetic affiliation within the Flavobacterium-Cytophaga rRNA homology group. Int. J. Syst. Bacteriol. 43:768-776.

73. Segers, P., P. Vandamme, P. L. Steyn, W. Mannheim, H. Willekens, M. Bauwens, J. De Ley, and K. Kersters. 1993. Phylogenetic studies of Flavobacterium and related organisms by DNA-rRNA hybridizations, p. 129 136. In P. J. Jooste (ed.), Advances in the taxonomy and significance of Flavobacterium, Cytophaga and related bacteria. University of the Orange Free State Press, Bloemfontein, South Africa.

74. Shivaji, S., M. K. Ray, N. S. Rao, L. Saisree, M. V. Jagannadham, G. Seshu Kumar, G. S. N. Reddy, and P. M. Bhargava. 1992. Sphingobacterium antarcticus sp. nov., a psychrotrophic bacterium from the soils of Schirmacher Oasis, Antarctica. Int. J. Syst. Bacteriol. 42:102-106.

75. Skerman, V. B. D., V. McGowan, and P. H. A. Sneath (ed.). 1980. Approved lists of bacterial names. Int. J. Syst. Bacteriol. 30:225-420.

76. Song, Y. L., J. L. Fryer, and J. S. Rohovec. 1988. Comparison of six media for the cultivation of Flexibacter columnaris. Fish Pathol. 23:91-94.

77. Soriano, S. 1945. Un nuevo orden de bacterias: Flexibacteriales. Cienc. Invest. (Buenos Aires) 1:92-93.

78. Stanier, R. Y. 1947. Studies on non-fruiting myxobacteria. I. Cytophaga johnsonae n. sp., a chitin-decomposing myxobacterium. J. Bacteriol. 53:297315 .

79. Stanier, R. Y. 1957. Order VIII. Myxobacterales Jahn 1915, p. 854-891. In R. S. Breed, E. G. D. Murray, and N. R. Smith (ed.), Bergey's manual of determinative bacteriology, 7 th ed. The Williams and Wilkins Co., Baltimore.

80. Steyn, P. L., J. J. Joubert, P. Segers, B. Pot, M. Vancanneyt, A. Willems, B. Hoste, and K. Kersters. 1993. The taxonomic position of some Gramnegative aerobic heparinase producing bacteria, p. 137-151. In P. J. Jooste (ed.), Advances in the taxonomy and significance of Flavobacterium, Cytophaga and related bacteria. University of the Orange Free State Press, Bloemfontein, South Africa.

81. Steyn, P. L., B. Pot, P. Segers, K. Kersters, and J. J. Joubert. 1992. Some novel aerobic heparin-degrading bacterial isolates. Syst. Appl. Microbiol. 15:137-143

82. Strohl, W. R., and L. R. Tait. 1978. Cytophaga aquatilis sp. nov., a facultative anaerobe isolated from the gills of freshwater fish. Int. J. Syst. Bacteriol. 28:293-303.

83. Takeuchi, M., and A. Yokota. 1991. Reclassification of strains of Flavobacterium-Cytophaga group in IFO culture collection. Inst. Ferment. Res. Commun. (Osaka) 15:83-96.

84. Takeuchi, M., and A. Yokota. 1992. Proposals of Sphingobacterium faecium sp. nov., Sphingobacterium piscium sp. nov., Sphingobacterium heparinum comb. nov., Sphingobacterium thalpophilum comb. nov., and two genospecies of the genus Sphingobacterium, and synonymy of Flavobacterium yabuuchiae and Sphingobacterium spiritivonum. J. Gen. Appl. Microbiol. 38:465-482.

85. Vandamme, P., J.-F. Bernardet, P. Segers, K. Kersters, and B. Holmes. 1994. New perspectives in the classification of the flavobacteria: description of Chryseobacterium gen. nov., Bergeyella gen. nov., and Empedobacter nom. rev. Int. J. Syst. Bacteriol. 44:827-831.

86. Vandamme, P., and J. De Ley. 1991. Proposal for a new family, Campylobacteraceae. Int. J. Syst. Bacteriol. 41:451-455.

87. Vandamme, P., J. Hommez, M. Vancanneyt, M. Monsieurs, B. T. Cookson, C. H. Wirsing von König, K. Kersters, and P. J. Blackall. 1995. Bordetella hinzii sp. nov., a species isolated from poultry and human sources. Int. J. Syst. Bacteriol. 45:37-45.

88. Vandamme, P., P. Segers, M. Vancanneyt, K. Van Hove, R. Mutters, J. Hommez, F. Dewhirst, B. Paster, K. Kersters, E. Falsen, L. A. Devriese, M. Bisgaard, K.-H. Hinz, and W. Mannheim. 1994. Ornithobacterium rhinotracheale gen. nov., sp. nov., isolated from the avian respiratory tract. Int. J. Syst. Bacteriol. 44:24-37.

89. Vandamme, P., M. Vancanneyt, B. Pot, L. Mels, B. Hoste, D. Dewettinck, L. Vlaes, C. Van Den Borre, R. Higgins, J. Hommez, K. Kersters, J.-P. Butzler, and H. Goossens. 1992. Polyphasic taxonomic study of the emended genus Arcobacter with Arcobacter butzleri comb. nov, and Arcobacter skirrowii sp. nov., an aerotolerant bacterium isolated from veterinary specimens. Int. J. Syst. Bacteriol. 42:344-356.

90. Van Der Meulen, H. J., W. Harder, and H. Veldkamp. 1974. Isolation and characterization of Cytophaga flevensis sp. nov., a new agarolytic flexibacterium. Antonie van Leeuwenhoek J. Microbiol. 40:329-346.

91. Van Landschoot, A., and J. De Ley. 1983. Intra- and intergeneric similarities of the rRNA cistrons of Alteromonas, Marinomonas (gen. nov.) and some other Gram-negative bacteria. J. Gen. Microbiol. 129:3057-3074.

92. Vauterin, L., J. Swings, and K. Kersters. 1991. Grouping of Xanthomonas campestris pathovars by SDS-PAGE of proteins. J. Gen. Microbiol. 137 $1677-1687$.

93. Vauterin, L., P. Yang, B. Hoste, M. Vancanneyt, E. L. Civerolo, J. Swings, and K. Kersters. 1991. Differentiation of Xanthomonas campestris pv. citri strains by sodium dodecyl sulfate-polyacrylamide gel electrophoresis of proteins, fatty acid analysis, and DNA-DNA hybridization. Int. J. Syst. Bacteriol. 41:535-542.

94. von Graevenitz, A. 1990. Revised nomenclature of Campylobacter laridis, 
Enterobacter intermedium, and "Flavobacterium branchiophila." Int. J. Syst. Bacteriol. 40:211.

95. Wakabayashi, H., G. J. Huh, and N. Kimura. 1989. Flavobacterium branchiophila sp. nov., a causative agent of bacterial gill disease of freshwater fishes. Int. J. Syst. Bacteriol. 39:213-216.

96. Wayne, L. G. 1982. Actions of the Judicial Commission of the International Committee on Systematic Bacteriology on requests for opinions published between July 1979 and April 1981. Int. J. Syst. Bacteriol. 32:464-465.

97. Woese, C. R. 1987. Bacterial evolution. Microbiol. Rev. 51:221-271.

98. Woese, C. R., S. Maloy, L. Mandelco, and H. D. Raj. 1990. Phylogenetic placement of the Spirosomaceae. Syst. Appl. Microbiol. 13:19-23.

99. Woese, C. R., L. Mandelco, D. Yang, R. Gherna, and M. T. Madigan. 1990 The case for relationship of the flavobacteria and their relatives to the green sulfur bacteria. Syst. Appl. Microbiol. 13:258-262.
100. Woese, C. R., E. Stackebrandt, T. J. Macke, and G. E. Fox. 1985. A phylogenetic definition of the major eubacterial taxa. Syst. Appl. Microbiol. 6:143-151.

101. Woese, C. R., D. Yang, L. Mandelco, and K. O. Stetter, 1990. The Flexibacter-Flavobacter connection. Syst. Appl. Microbiol. 13:161-165.

102. Yabuuchi, E., T. Kaneko, I. Yano, C. W. Moss, and N. Miyoshi. 1983. Sphingobacterium gen. nov., Sphingobacterium spiritivorum comb. nov., Sphingobacterium multivorum comb. nov., Sphingobacterium mizutae sp. nov., and Flavobacterium indologenes sp. nov.: glucose-nonfermenting gram-negative rods in CDC groups IIk-2 and IIb. Int. J. Syst. Bacteriol. 33:580-598.

103. Yabuuchi, E., and C. W. Moss. 1982. Cellular fatty acid composition of strains of three species of Sphingobacterium gen. nov. and Cytophaga johnsonae. FEMS Microbiol. Lett. 13:87-91. 